\title{
Origin, Evolution and Homologies of the Weberian Apparatus: A New Insight
}

\author{
Origen, Evolución y Homologías del Aparato Weberiano: Un Nuevo Acercamiento \\ Rui Diogo
}

DIOGO, R. Origin, evolution and homologies of the Weberian apparatus: a new insight. Int. J. Morphol., 27(2):333-354, 2009.

SUMMARY: The Weberian apparatus is essentially a mechanical device improving audition, consisting of a double chain of ossicles joining the air bladder to the inner ear. Despite being one of the most notable complex systems of teleost fishes and the subject of several comparative, developmental and functional studies, there is still much controversy concerning the origin, evolution and homologies of the structures forming this apparatus. In this paper I provide a new insight on these topics, which takes into account the results of recent works on comparative anatomy, paleontology, and ontogeny as well as of a recent extensive phylogenetic analysis including not only numerous otophysan and non-otophysan extant otocephalans but also ostariophysan fossils such as $\dagger$ Chanoides macropoma, $\dagger$ Clupavus maroccanus, $\uparrow$ Santanichthys diasii, $\uparrow$ Lusitanichthys characiformis, $\uparrow$ Sorbininardus apuliensis and $\uparrow$ Tischlingerichthys viohli. According to the evidence now available, the Weberian apparatus of otophysans seems to be the outcome of a functional integration of features acquired in basal otocephalans and in basal ostariophysans, which were very likely not directly related with the functioning of this apparatus, and of features acquired in the nodes leading to the Otophysi and to the clade including the four extant otophysan orders, which could well have been the result of a selection directly related to the functioning of the apparatus.

KEY WORDS: Evolution; Functional anatomy; Ostariophysi; Otocephala; Otophysi; Phylogeny; Teleostei; Weberian apparatus.

\section{INTRODUCTION}

The Weberian apparatus is one of the most notable complex systems of teleost fishes (Weber, 1820). It is found in extant otophysans, i.e. cypriniforms, characiforms, siluriforms and gymnotiforms, but, as will be explained below, was seemingly present in a 'plesiomorphic' form in basal, now extinct, otophysan fishes such as $\dagger$ Chanoides macropoma, $\dagger$ Clupavus maroccanus, $\dagger$ Santanichthys diasii, and $†$ Lusitanichthys characiformis (see Fig. 1) (e.g. Gayet, 1981, 1985, 1986a, 1986b; Patterson, 1984; Taverne, 1995, 2005; Cavin, 1999; Filleul \& Maisey, 2004). The apparatus (Figs. 2-6) is essentially a mechanical device improving audition, consisting of a double chain of ossicles joining the air bladder to the inner ear, associated with a modification of the pars inferior of the labyrinths of the inner ear and of the anterior portion of the swimbladder (camera aerea Weberiana) (e.g. Weber; Sagemehl, 1885; Bridge \& Haddon, 1894; Schreiber, 1935; Franz, 1937; Poggendorf, 1952; Kleerekoper \& Roggenkamp, 1959; Alexander, 1961ab, 1964ab, 1965; Chardon, 1968; Weiss et al., 1969; Vandewalle, 1975). Chardon et al. (2003) provided a recent review on the comparative anatomy, functional morphology and evolution of the Weberian apparatus. Some parts of the overview provided in the present paper are based in Chardon et al.'s work. However, there are significant differences between this paper and that work. One of the main differences is that this overview also takes into account several works that have provided relevant information on the subject after the writing of Chardon et al's (2003) paper, which, thus, were not considered in that paper (e.g. Grande \& Shardo, 2002; Grande \& Braun, 2002; Coburn \& Chai, 2003; De Pinna \& Grande, 2003; Filleul \& Maisey; Grande \& Young, 2004; Grande \& De Pinna, 2004; Taverne, 2005). But the most significant original contribution of the present paper is that it presents a discussion on the homologies and evolution of the Weberian apparatus that is directly based on the phylogenetic results of an extensive cladistic analysis including not only representatives of the four extant otophysan orders, of the Gonorynchiformes and of the Clupeomorpha, but also ostariophysan fossils such as 
$\dagger$ Chanoides macropoma, †Clupavus maroccanus, $\dagger$ Santanichthys diasii, $†$ Lusitanichthys characiformis, $\dagger$ Sorbininardus apuliensis and $†$ Tischlingerichthys viohli (Diogo, 2007; see Fig. 1). This thus allows having a more complete, broader view on the phylogeny and evolution of the otophysans and their closely related groups, thus allowing, for example, to cladistically tracing the homologies and evolution of some key Weberian structures.

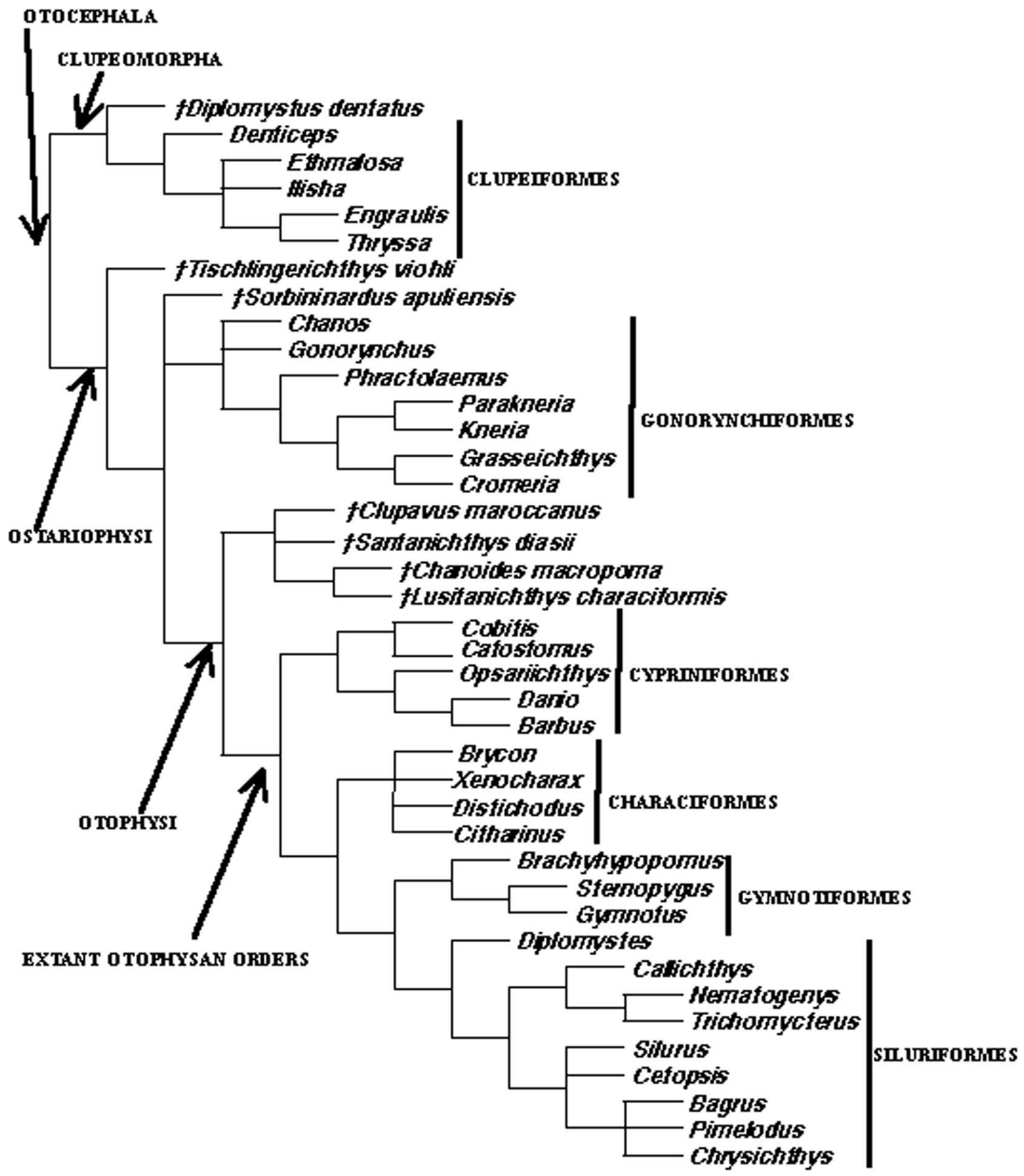

Fig. 1. Phylogenetic relationships of representative extant and fossil otocephalans, modified from Diogo (2007) (the nomenclature of the taxa included in the cladogram follows that of Diogo's 2007 work). 


\section{MATERIAL AND METHOD}

The phylogenetic framework for the discussions provided in the present paper is based on the results of a recent cladistic analysis of teleostean higher-level phylogeny including 271 phylogenetic osteological and myological characters and 70 extant and fossil terminal taxa; the results obtained for the Otocephala clade (clupeomorphs + ostariophysans) are shown in Figure 1. The actinopterygian specimens examined for the present study are from the Laboratory of Functional and Evolutionary Morphology of the University of Liège (LFEM), the Museo Nacional de Ciencias Naturales de Madrid (MNCN), the American Museum of Natural History (AMNH), the Academy of Natural Sciences of Philadelphia (ANSP), the Chinese Academy of Sciences at Wuhan (CASW), the California Academy of Sciences (CAS), the Illinois Natural History Survey (INHS), the Musée Royal de l'Afrique Centrale (MRAC), and the National Museum of Natural History (USNM). The list of specimens is given below; the trypsine-cleared and alizarine-stained (c\&s) or alcohol fixed (alc) condition of these specimens is given in parentheses following the number of specimens observed. Dissections were made using a Wild M5 dissecting microscope equipped with a camera lucida. The information regarding the fossil taxa mentioned in the text is based on an extensive overview of the literature available (e.g. Taverne, 1995, 1999; Gayet, 1981, 1985; Patterson; Filleul \& Maisey). The nomenclature of the anatomical structures discussed in the present paper follows that of Diogo (2007).

Non-teleostean actinopterygians: Acipenser sturio: MNCN 152172, 3 (alc). Amia calva: MNCN 35961, 1 (alc), 1 (c\&s). Lepisosteus osseus: ANSP 107961, 2 (alc); ANSP 172630, 1 (alc); MNCN 246557, 1 (c\&s). Lepisosteus platyrhincus: AMNH 74789, 2 (alc). Polypterus bichir: MNCN 1579, 7 (alc), 1 (c\&s). Psephurus gladius: CASW, uncatalogued, 1 (alc). Elopomorphs: Albula vulpes: MNCN 52124, 2 (alc). Anguilla anguilla: MNCN 41049, 3 (alc). Elops lacerta: LFEM, 2 (alc). Elops saurus: MNCN 48752, 2 (alc). Conger conger: MNCN 1530, 5 (alc). Eurypharynx pelecanoides: AMNH 44315, 1 (alc); AMNH 44344, 1 (alc). Megalops cyprinoides: MNCN 48858, 3 (alc). Notacanthus bonaparte: MNCN 107324, 3 (alc). Osteoglossomorphs: Hiodon tergisus: MNCN 36019, 3 (alc). Mormyrus niloticus: LFEM, 1 (alc). Mormyrus tapirus: MNCN 80593, 3 (alc); MNCN 85283, 1 (alc). Pantodon buchholzi: MNCN 73493, 4 (alc). Xenomystus nigri: MNCN 227824, 25 (alc). Clupeomorphs: Denticeps clupeoides: MRAC 76-032-P1, 2 (alc). Engraulis encrasicolus: MNCN 68048, 2 (alc); MNCN 65097, 8 (alc); MNCN 1099, 3 (alc). Engraulis sp: MNCN 48896, 3 (alc). Ethmalosa fimbriata: MNCN 48865, 3 (alc). Ilisha fuerthii: MNCN 49338, 8 (alc). Thryssa setirostris: MNCN 49294, 2 (alc). Ostariophysans: Bagrus bajad: LFEM, 1 (alc), 1 (c\&s). Bagrus docmak: MRAC 8607-P-512, 1 (alc). Barbus barbus: LFEM, 1 (c\&s). Barbus guiraonis: MNCN 245730, 3 (alc). Brachyhypopomus brevirostris: LFEM, 2 (alc). Brachyhypopomus sp: INHS 89761, 2 (alc). Brycon guatemalensis: MNCN 180536, 3 (alc). Brycon henni: CAS 39499, 1 (alc). Callichthys callichthys: USNM 226210, 2 (alc). Catostomus commersonii: MNCN 36124, 10 (alc). Citharinus sp.: 86016-P-72, 3 (alc). Cetopsis coecutiens: USNM 265628, 2 (alc). Chanos chanos: USNM 347536, 1 (alc), LFEM, 1 (alc). Chrysichthys auratus: UNB, 2 (alc). Chrysichthys nigrodigitatus: LFEM, 1 (c\&s). Cobitis paludica: MNCN 248076, 7 (alc). Cromeria nilotica: MRAC P.141098, 2 (alc). Danio rerio: MNCN, 10 (alc). Diplomystes chilensis: LFEM, 3 (alc). Distichodus notospilus: MRAC A0-048-P-2630, 3 (alc). Gonorynchus gonorynchus: LFEM, 2 (alc). Gonorynchus greyi: FMNH 103977, 1 (alc). Grasseichthys gabonensis: MRAC 73-002-P-264, 3 (alc). Gymnotus carapo: INHS 35493, 2 (alc). MNCN 115675, 2 (alc). Kneria wittei: MRAC P-33512, 2 (alc). Nematogenys inermis: USNM 084346, 2 (alc). Opsariichthys uncirostris: MNCN 56668, 3 (alc). Parakneria abbreviata: MRAC 99-090-P703, 3 (alc). Phractolaemus ansorgii: MRAC P.137982, 3 (alc). Pimelodus blochii: LFEM, 2 (alc), 1 (c\&s). Silurus aristotelis: LFEM, 2 (alc). Silurus glanis: LFEM, 2 (alc). Sternopygus macrurus: CAS 48241, 1 (alc); INHS 62059, 2 (alc). Trichomycterus areolatus: LFEM, 2 (alc). Xenocharax spilurus: MRAC A0-048-P-2539, 3 (alc). Euteleosts: Alepocephalus rostratus: MNCN 108199, 2 (alc). Argentina brucei: USNM 239005, 2 (alc). Argentina sphyraena: MNCN 001134, 12 (alc); MNCN 78530, 5 (alc). Astronesthes niger: MNCN 1102, 1 (alc). Aulopus filamentosus: MNCN 1170, 6 (alc). Bathylagus euryops: MNCN 124597, 1 (alc). Bathylagus longirostris: USNM 384823, 2 (alc). Bathylagus tenuis: MNHN 2005-1978, 2 (alc). Chlorophthalmus agassizi: MNCN 1193, 3 (alc); MNCN 1182, 5 (alc). Coregonus lavaretus: MNCN 75424, 1 (alc). Coregonus tugun: MNCN 75422, 2 (alc). Esox lucius: MNCN 197706, 5 (alc). Galaxias maculatus: USNM 344889, 2 (alc). Osmerus eperlanus: MNCN 193795, 11 (alc). Osmerus mordax: USNM 32565, 2 (alc). Plecoglossus altivelis: MNCN 192036, 1 (alc). Retropinna retropinna: AMNH 30890, 1 (alc). Salmo trutta: MNCN 136179, 2 (alc), 1 (c\&s); MNCN 16373, 2 (alc); MNCN 40685, 2 (alc). Salmo sp: MNCN 48863, 2 (alc). Searsia koefoedi: USNM 206896, 2 (alc). Stokellia anisodon: AMNH 31037, 1 (alc). Stomias boa: MNCN 74444, 8 (alc); MNCN 74456, 4 (alc). Thymallus thymallus: MNCN 115147, 1 (alc); MNCN 114992, 1 (alc). Umbra limi: MNCN 35672, 2 (alc); 36072, 2 (alc). Umbra krameri: MNCN 36659, 3 (alc). Xenodermichthys copei: MNCN 78950, 2 (alc); MNCN 1584, 2 (alc); USNM 215527, 2 (alc). 

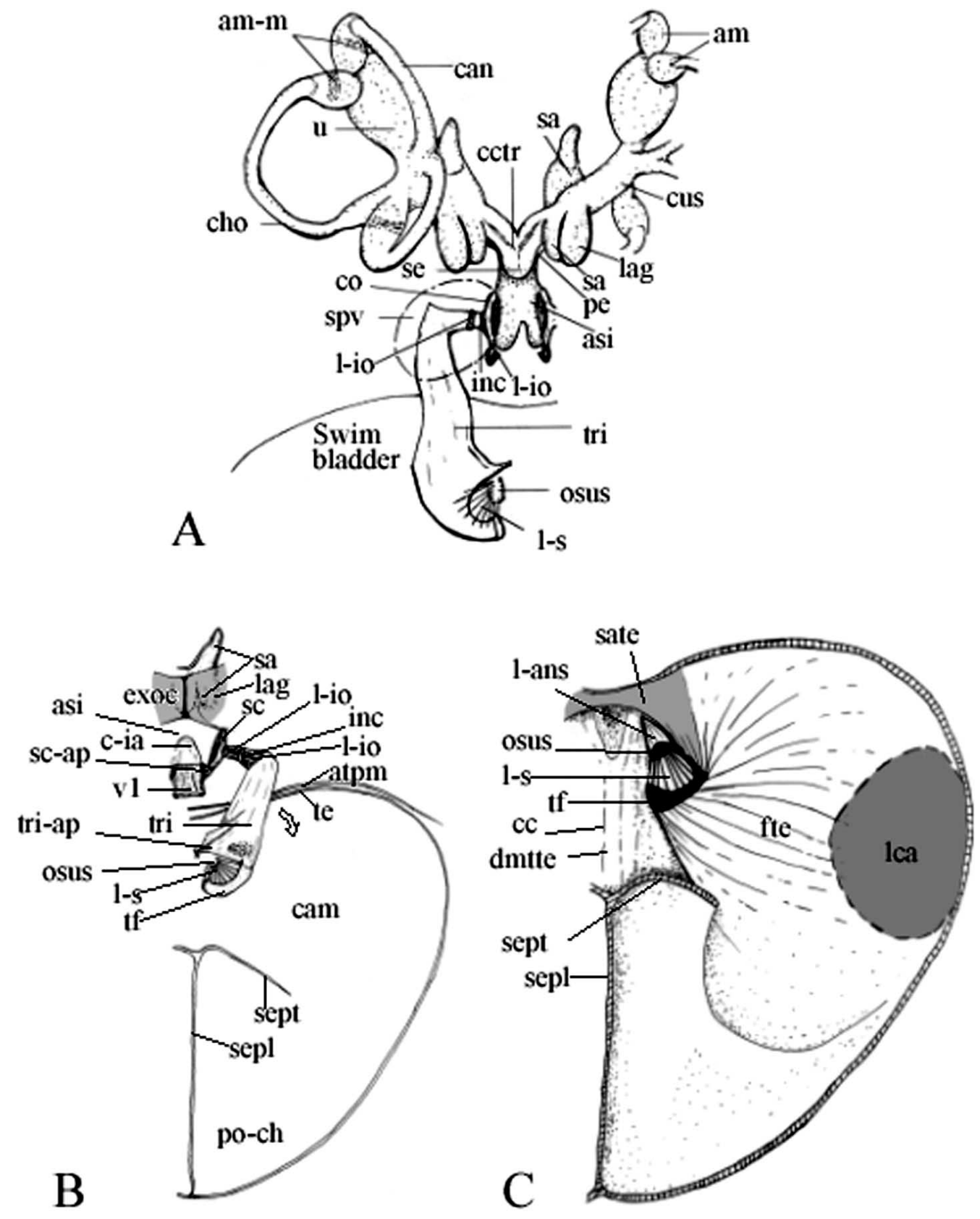

Fig. 2. Ictalurus nebulosus (modified from Chardon et al., 2003; the identity of the structures illustrated follows that used by the authors of the original drawing). A) Dorsal view of labyrinths, sinus impar and ossicles. The right labyrinth was pushed laterally for showing the canalis utriculo-saccularis. B) Dorsal half of the swimbladder with ossicles and hind part of labyrinths. Notice the exoccipital bridge (in light grey) covering the saccules and lagenas. The ossicles were pulled laterally (arrow) as if the swimbladder was compressed. C) Ventral half of the swimbladder showing the thin median area and its anterior arch and the lateral cutaneous areae (both in light grey). am, ampulla; am-m, macula of ampulla; asi, atria sinus imparis; atpm, anterior transversal peritoneal membrane; c-ia, cartilago interatrialis; cam, camera aerea Weberiana; can, anterior semicircular canal; cc, complex centrum; cctr, canalis communicans transversus; cho, horizontal semicircular canal; co, concha of scaphium; cus, utriculo-saccular canal; dmtte; dorsomesial area of thin tunica externa ("median slit"); fte, fibers of tunica externa inserting on transformator tripodis; inc, intercalarium; l-ans, anterior ligament of os suspensorium; l-io, interossicular ligament; l-s, suspensor ligament; lag, lagena; lca, lateral cutaneous area; osus, os suspensorium; pe, perilymphatic space; poch, posterior ("hydrostatic") chamber of swimbladder; sa, saccule; sate, supple area of tunica externa; sc, scaphium; sc-pa, articular process of scaphium; se, sinus endolymphaticus; sepl, longitudinal septum of swimbladder; sept, transversal septum of swimbladder; spv, saccus paraventralis; te, tunica externa of swimbladder; tf, transformator tripodis; tri, tripus; tri-ap, articular process of tripus; $\mathbf{u}$, utricle; $\mathbf{v 1}$, free vertebra 1 . 


\section{RESULTS AND DISCUSSION}

\section{Homologies of the Weberian ossicles}

With exception to the shape of the os suspensorium (see below), the overall configuration of the Weberian apparatus is somewhat constant in extant otophysans (Figs. 2, 3D, 4B, C, D, 6B; e.g. Weber; Sagemehl; Bridge \& Haddon; Chranilov, 1927, 1929; Alexander, 1961b, 1964ab; Popper, 1971; De la Hoz \& Chardon, 1984; Grande \& Shardo 2002; Chardon et al.). The curved posterior portion of the tripus, i.e. the transformator tripodis, is on the one hand in contact with the swimbladder and, on the other hand, connected by the suspensor ligament to the os suspensorium (Figs. 2, 3D, 6B). The anterior portion of the tripus is usually connected to the intercalarium, this latter being connected to the scaphium, and, thus, to the concha scaphii, by the interossicular ligament (Figs. 2, 3D, $4 \mathrm{~B}, \mathrm{C}, \mathrm{D}, 6 \mathrm{~B}$; contrary to the os suspensorium, the intercalarium and the scaphium exhibit a characteristic, rather similar configuration in plesiomorphic extant otophysans, but the configuration of these two latter elements may vary in some derived otophysans, being for example very small or even absent in some catfishes: see e.g. Chardon, 1968; Chardon et al. Such a configuration of the Weberian ossicles and associated ligaments thus makes that, by changing the volume of the swimbladder, the tripus, and, consequently, the anterior Weberian ossicles, are moved; these movements are then transmitted to the sinus impar and to the labyrinths of the inner ear (Fig. 2, 3D). Above the scaphium usually lies a small ossicle, the claustrum (Fig. 4B, C, D). This ossicle does not really make part of the vibration-transmitting chain between the swimbladder and the inner ear. Authors such as Grande \& De Pinna (2004) suggested that it might instead form a dorsolateral bony wall around the anterior portion of the neural canal, in the space between the back of the skull and the beginning of the neural arch series (see below).

Developmental studies have described somewhat different ontogenetic origins for the Weberian ossicles of extant otophysans, thus suggesting different homologies between these ossicles and the postcranial structures of other teleosts (e.g. Weber; Watson, 1939; Bamford, 1948; Butler; Hoedemann, 1960ab; Rosen \& Greenwood, 1970; Kulshrestha, 1977; Fink \& Fink, 1981, 1996; Radermaker et al., 1989; Vandewalle et al., 1989, 1990; Bogutskaia, 1991; Fukushima et al., 1992; Ichiyanagi et al., 1993, 1996, 1997; Coburn \& Futey, 1996; Coburn \& Grubach, 1998; Heyd \& Pfeiffer, 2000; Grande \& Shardo, 2002; Chardon et al.; Coburn \& Chai; De Pinna \& Grande; Grande \& De Pinna, 2004; Grande \& Young, 2004).
Three main general theories of the homologies of the Weberian ossicles have been proposed in the literature: that these ossicles are homologous with the mammalian ear bones (e.g. Weber); that they represent modified portions of the first free vertebrae (e.g. Bamford; Rosen \& Greenwood); or that they are originated from modified portions of the first free vertebrae but also from the ossification of other structures such as mesenchyme, ligaments and/or the swimbladder (e.g. Watson; Kulshresta; Chardon et al.). The first of these theories (Weber) has been discarded by the accumulation of data on vertebrate phylogeny, ontogeny and evolution. However, there is still controversy on whether the Weberian ossicles are exclusively, or just partially, originated by modifications of certain bony vertebral structures found in other teleosts, and even on which of these bony structures might have been modified in order to be included in the Weberian apparatus of extant otophysans (e.g. neural arches, supraneurals, ribs and/or parapophyses of the first, second and/or third free vertebra; see Chardon et al.; De Pinna \& Grande; Grande \& De Pinna, 2004; Grande \& Young, 2004).

\section{Scaphium}

Authors such as Bamford; Butler; Rosen \& Greenwood stated that the scaphium is exclusively formed in ontogeny from neural arch 1 (Fig.6). Others, such as Watson; Kulshresta; Rademarker et al.; Vandewalle et al. (1990); Grande \& Young (2004), stated that this ossicle is formed from the neural arch 1 plus ossification of mesenchyme. According to some of these latter authors (e.g. Watson), the mesenchyme contributes to the formation of the concha scaphii. In the recent paper of Grande \& De Pinna (2004), these researchers considered that the scaphium of plesiomorphic extant otophysans (e.g. Cypriniformes) is derived mainly from the neural arch 1 but also from a mesenchymous contribution, which may be a phylogenetic remnant of the cartilages positioned between the exoccipitals and first neural arch in fishes such as gonorynchiforms.

The phylogenetic scenario shown in Fig.1, including basal otophysan fossils such as $†$ Chanoides macropoma, $\dagger$ Lusitanichthys characiformis, $†$ Santanichthys diasii and $\dagger$ Clupavus marocannus, supports a single, unique origin of the characteristic scaphium of extant otophysans (see below). And, although these fossils cannot clarify if the mesenchyme contributes or not for a small portion of the scaphium, they do provide support for a major contribution of the first neural arch to the scaphium of extant otophysans, showing a somewhat transitional stage between non-otophysans and the latter fishes (e.g. Patterson; Fink \& Fink, 1996). In fact, as noted by these authors, the 'plesiomorphic' scaphia of species such as †Chanoides macropoma show typical features of the scaphia of extant otophysans, such as its 
overall shape and the well-defined, thin ventral articulation with the first centrum. But they also exhibit typical features of the first neural arch of extant non-otophysans, such as the presence of foramina for dorsal and ventral nerve roots (Figs. 4A, 5D; most extant otophysans lack such foramina, see below).

\section{Intercalarium}

Regarding the intercalarium, authors such as Bamford; Vandewalle et al.; Bogutskaia (1991), Fukushima et al.; Ichiyanagi et al. $(1993,1996)$ and Grande and De Pinna (2004) stated that this ossicle develops exclusively from the second neural arch. Others (e.g. Watson; Butler, 1960; Kulshresta; Chardon et al.), suggested that it develops from this neural arch plus an ossification of the interossicular ligament (Fig. 3C, D). In my opinion, understanding the origin of the intercalarium is crucial to discuss the origin and evolution of the Weberian apparatus as a whole. In fact, the two main evolutionary hypotheses proposed so far for the origin and evolution of the chain of Weberian ossicles and ligaments between the swimbladder and the inner ear are deeply related with the two main types of homologies proposed for the intercalarium. One of these evolutionary hypotheses, which I call 'indirect hypothesis', was formulated by authors such as Rosen \& Greenwood (Fig.6). It states that the ligamentous connection between the tripus and the scaphium was initially an indirect one, the tripus being connected by a ligament to the neural arch 3 (lig. E of Fig. $6 \mathrm{~A}$ ), this neural arch being connected by a second ligament to the modified neural arch 2 (lig. $\mathrm{C}$ of Fig. 6A), and this latter being connected by a third ligament to the modified neural arch 1 (lig. B of Fig. 6A). Only later in evolution the connection with the third neural arch was lost, giving thus the characteristic configuration seen in most extant otophysans: a ligament between the tripus and the intercalarium, and another between the intercalarium and the scaphium (Fig. 6B). The other hypothesis, which I call the 'direct hypothesis', was formulated by authors such as Watson; Chardon et al. It states that initially the connection between the tripus and the scaphium was a direct one, with a single ligament connecting these two structures (Fig. 3C). Then, there was an ossification of part of this ligament giving the manobrium of the intercalarium, which only attached to the modified second neural arch later in evolution, forming thus the complete intercalarium (Fig. 3D). Thus, an ontogenetic origin of the intercalarium exclusively from the second neural arch, with a connection between this bone and the interossicular arriving only latter in development, might be used by some researches as an argument in favor of the direct hypothesis. Alternatively, an initial ontogenetic origin of the intercalarium from two different parts, one from the second neural arch and the other from an ossification of the ligament interossicular, with the connection between these two parts occurring only later in development, might be used by some authors as an argument in favor of the indirect hypothesis. Developmental studies on the Weberian apparatus should, therefore, pay special importance to the formation of the interossicular ligament and its connections to the surrounding Weberian structures.

Although the interossicular ligament has not been conserved in fossils such as $†$ Chanoides macropoma, $\dagger$ Chanoides chardoni, $\dagger$ Lusitanichthys characiformis, $\dagger$ Lusitanichthys africanus, $†$ Santanichthys diasii and $\dagger$ Clupavus maroccanus, these fossils do bring some light on the homologies of the intercalarium of extant otophysans (note: in the reconstruction of $†$ Chanoides macropoma shown in Fig. 4A, Patterson, draw the ligament interossicular, but this was due to the functional interpretation of that author, not to a real preservation of this ligament in the fossil). Firstly, these fossils do suggest that the second neural arch contributed to the formation of the intercalarium of extant otophysans. This because, as will be seen below, although the 'plesiomorphic' intercalaria of these fossils clearly show some features in common with the intercalaria of extant otophysans, they also exhibit typical features of the second neural arch of other fishes. For example, they are large structures that cover almost all the dorsal surface of the second centrum, and they exhibit foramina for ventral and dorsal nerve roots in $†$ Chanoides macropoma (Figs. 4A, 5; see also below).

Secondly, the overall configuration of the Weberian ossicles of these fossils seems to support the direct evolutionary hypothesis mentioned above for the origin and evolution of the Weberian apparatus. For instance, the manobrium of the intercalarium of $\dagger$ Chanoides macropoma described by Patterson is separated from the main bony of the intercalarium, thus being seemingly a sesamoid ossification, as proposed by the defenders of the direct hypothesis (Fig.4A). Moreover, the intercalarium of the Weberian apparatus of $\dagger$ Lusitanichthys characiformis, $\dagger$ Santanichthys diasii and $\dagger$ Clupavus maroccanus either lacked a manobrium or had a small manobrium that, by being somewhat separated from the main body of the intercalarium (as in $\dagger$ Chanoides macropoma) was possibly lost (Fig. 5; see also Gayet, 1985; Gayet \& Chardon, 1987; Chardon et $a l$.). Any of these two options would support the direct hypothesis. This because they would suggest that in those basal otophysan fossils with a 'plesiomorphic', and perhaps functional, Weberian apparatus the manobrium was still missing or was (as in $†$ Chanoides macropoma) possibly present but still loosely attached to the main body of the intercalarium (suggesting that the interossicular ligament would already be partially ossified but the resulting sesamoid 


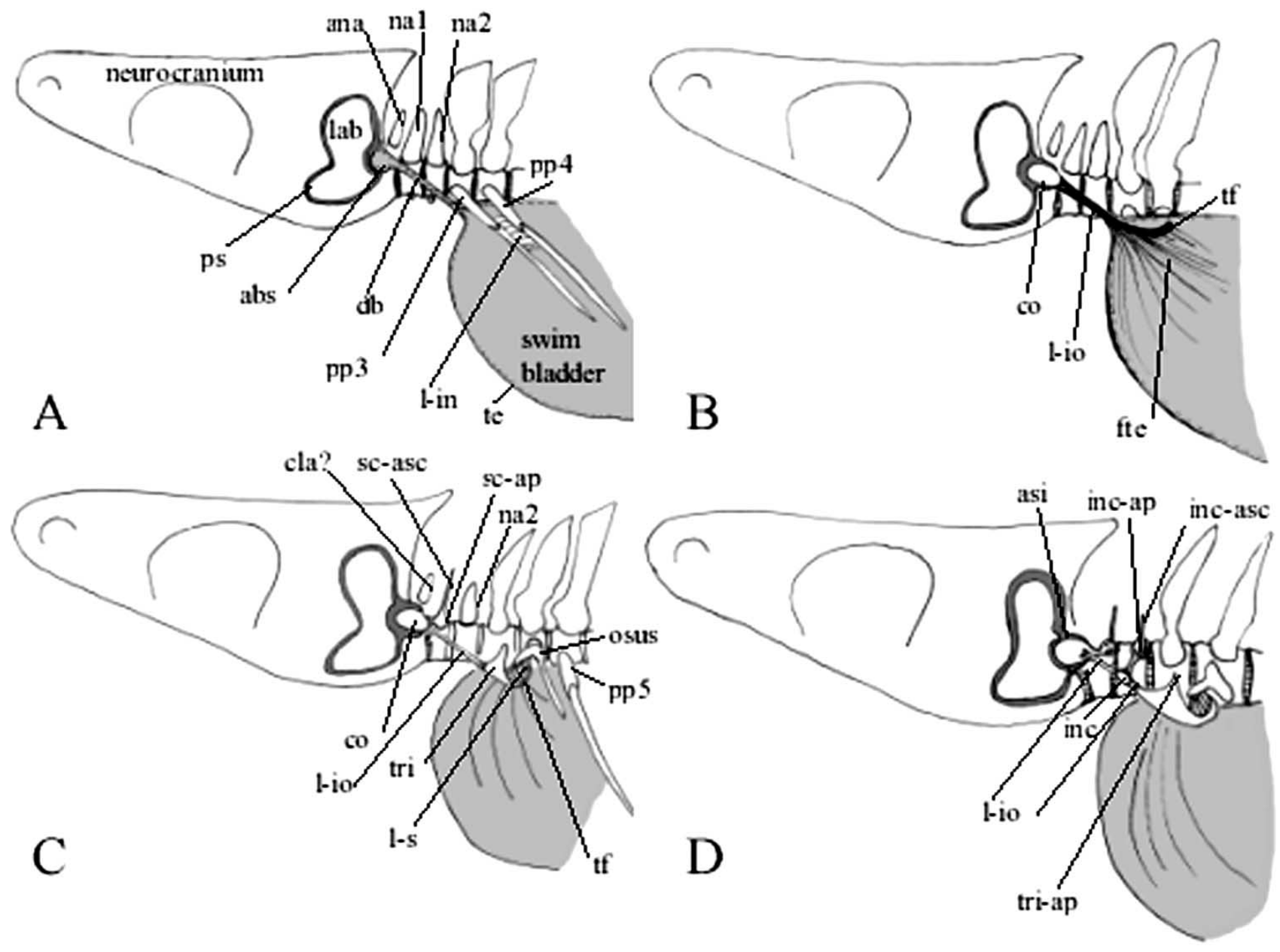

Fig. 3. Schematic illustration of Chardon et al.'s (2003) hypothesis about the origin of the Weberian apparatus (modified from Chardon et al., 2003; the identity of the structures illustrated follows that used by the authors of the original drawing). A) 'Clupeiformlike' stage with an otophysic connection. The anterior duct between the swimbladder and the bulla is coated by the tunica externa; the labyrinth is surrounded by a perilymphatic space. The first two haemal arches are reduced. Parapophyses and ribs 3 and 4 are joined by an intercostal ligament. B) Fully hypothetical stage. The haemal arches are not figured. The endodermic epithelium and splanchnopleura have disappeared in the duct and bulla. The duct, reduced to the fibrous tunica externa, becomes the interossicular ligament; ossification of the wall of the bulla produces the concha scaphii; the wall of the swimbladder ossifies into the transformator of the tripus where the fibers of the tunica externa exert a traction. The parapophyses of free vertebrae 3 and 4 are not figured. C) $\dagger$ Chanoides macropoma and/or $\dagger$ Lusitanichthys characiformis-like stage. The anterior neural arch (or a paired supraneural?) becomes the claustrum. The first neural arch transforms into the scaphium (articular and ascendens processes) and fuses with the concha. The third haemal and possibly the third rib fuse with the transformator and become the tripus. The fourth haemal arch transforms into the os suspensorium, which remains attached to the third haemal arch by an intercostal ligament; that latter becomes the suspensor ligament. An osseous nodule probably appears in the interossicular ligament: the manubrium of the future intercalarium (not figured). D) Stage of extant otophysans. The second neural arch attaches to the manubrium to form the intercalarium. abs, anterior bulla of swimbladder; ana, anterior neural arch; asi, atrium sinus imparis; cla, claustrum; co, concha of scaphium; db, duct to the bulla; fte, ichthyocoll fibers of tunica externa inserting on transformator tripodis; inc, intercalarium; inc-ap, articular process of intercalarium; inc-asc, ascendens process of intercalarium; l-io, interossicular ligament; l-in, intercostal (intervertebral) ligament; l-s, suspensor ligament; lab, labyrinth; na1, 2, neural arches 1 and 2; osus, os suspensorium; pp3, 4, 5, parapophyses of free vertebrae 3, 4 and 5; ps, perilymphatic space (in dark grey); sc-ap, articular process of scaphium; sc-asc, ascendens process of scaphium; te, tunica externa of swimbladder; tf, transformator tripodis; tri, tripus; tri-ap, articular process of tripus. 
ossification was still not firmly attached to the main body of the intercalarium: Fig. 3C, D). It should also be noted here that, as stressed by Chardon et al., from a purely morphofunctional point of view, if one applies the indirect hypothesis suggested by Rosen \& Greenwood to basal otophysan fossils such as $†$ Lusitanichthys characiformis or $\dagger$ Santanichthys diasii, this seems to lead to a rather unfunctional, unlikely Weberian apparatus. As can be seen in Figure 5B and 5D, these fossils seemingly had large and apparently rather immobile neural arches 2 (= main body of intercalarium) and 3. Moreover, these structures were essentially situated dorsally to the tripus. Thus, with such a configuration, a ligament joining the tripus to these neural arches (lig. E of Fig. 6A), as proposed by the indirect hypothesis of Rosen \& Greenwood, would be essentially oriented in a dorsoventral, and not in an oblique, direction. Therefore, the movements of the tripus would hardly provoke an anteroposterior displacement of the third neural arch and/ or of the main body of the intercalarium, and thus more hardly provoke, by means of still another ligament between these latter structures and the scaphium (lig. B of Fig. 6A), any significant displacement of the scaphium.

In fact, as the intercalarium of basal otophysan fossils such as $\dagger$ Lusitanichthys characiformis, $\uparrow$ Santanichthys diasii and $\dagger$ Clupavus maroccanus does not lie within the line of action between the tripus and the scaphium (Fig. 5), there are apparently only two ways in which the Weberian apparatus of these fossils might have been functionally efficient. One is by having a direct ligament between the tripus and the scaphium (Fig.3C). The other is by having a sesamoid ossification of this ligament possibly associated with the main body of the intercalarium, as was seemingly the case in e.g. $\dagger$ Chanoides macropoma (Figs.3D,4A). Therefore, in view of the morphofunctional and paleontogical data available, I am inclined to favor the direct hypothesis mentioned above for the origin and evolution of the Weberian interossicular ligament. Thus, I am inclined to agree with an evolutionary origin (but not necessarily with a developmental origin: see below) of the intercalarium from both the second neural arch and a sesamoid ossification of the interossicular ligament. Moreover, my own anatomical comparisons between extant otophysans and extant representatives of closely related groups such as the gonorynchiforms and clupeomorphs (see Fig.1) also raise objections for the indirect hypothesis of authors such as Rosen \& Greenwood. This because, among all the extant members I have dissected from these two latter groups, I never found a well-defined ligament between the parapophysis and/or rib of the third free vertebra and the third and/or second arch as that proposed by these authors.

Developmental data is, of course, very important for discussing homologies. As explained above, the developmental data available so far does however not help to clarify the origin of the intercalarium. Some authors state that this ossicle develops ontogenetically from the second neural arch plus an ossification of the interossicular ligament, while others state that it develops exclusively from the second neural arch. However, it is also important to stress that developmental data is not the only, and in some specific cases not even the most reliable, type of data to be considered in discussions of homology. Development does not always recapitulates evolution; evolutionary innovations can also be related, and often are, to non-terminal additions (see e.g. Mabee, 1989ab, 1993; Gould, 2002). This is well-known in theory, but unfortunately continues to be too often neglected in practical discussions of homology, as pointed out by authors such as Gould (2002) and Diogo (2007).

\section{Claustrum}

As stated by De Pinna \& Grande; Grande \& De Pinna (2004), the homology of the claustrum has also been, and continues to be, controversial. The data available from the fossil specimens available of $†$ Chanoides macropoma, $\dagger$ Lusitanichthys characiformis, $†$ Santanichthys diasii and $\dagger$ Clupavus maroccanus does not help to clarify the homologies of this ossicle, as it is apparently missing in these specimens (Figs. 4A, 5). According to Patterson, Gayet (1981, 1985), Taverne (1995) and Filleul \& Maisey, the lack of this ossicle in $†$ Chanoides macropoma, $†$ Lusitanichthys characiformis, $†$ Santanichthys diasii and $†$ Clupavus maroccanus might be due to a real absence of the ossicle or, perhaps more likely, to its bad preservation in the fossil record. The apparent presence, according to Taverne's (2005: Fig.12) interpretation, of a well-developed claustrum in $\dagger$ Chanoides chardoni seems to support this latter hypothesis.

Concerning the developmental data available, different authors have different interpretations. For instance, Fink \& Fink (1981) argued that the claustrum develops from a dissociated portion of the first neural arch. In turn, Watson; Vandewalle et al. (1990) stated that this ossicle develops from the ossification of mesenchyme, while Coburn \& Futey (1996) defended that it develops from the first supraneural. De Pinna \& Grande; Grande \& De Pinna (2004) reviewed the arguments used to support each of these three hypotheses. These latter authors argued that the developmental data available strongly supports a fourth hypothesis: that the claustrum was originated from a modified accessory neural arch, a structure usually present in fishes such as clupeomorphs (Fig. 3A). It should be noted that, apart evidence from developmental data, De Pinna \& Grande; Grande \& De Pinna (2004) also provided topological and functional arguments in favor of their hypothesis. They argued that the claustrum, like the accessory neural arch, is topologically positioned as the 

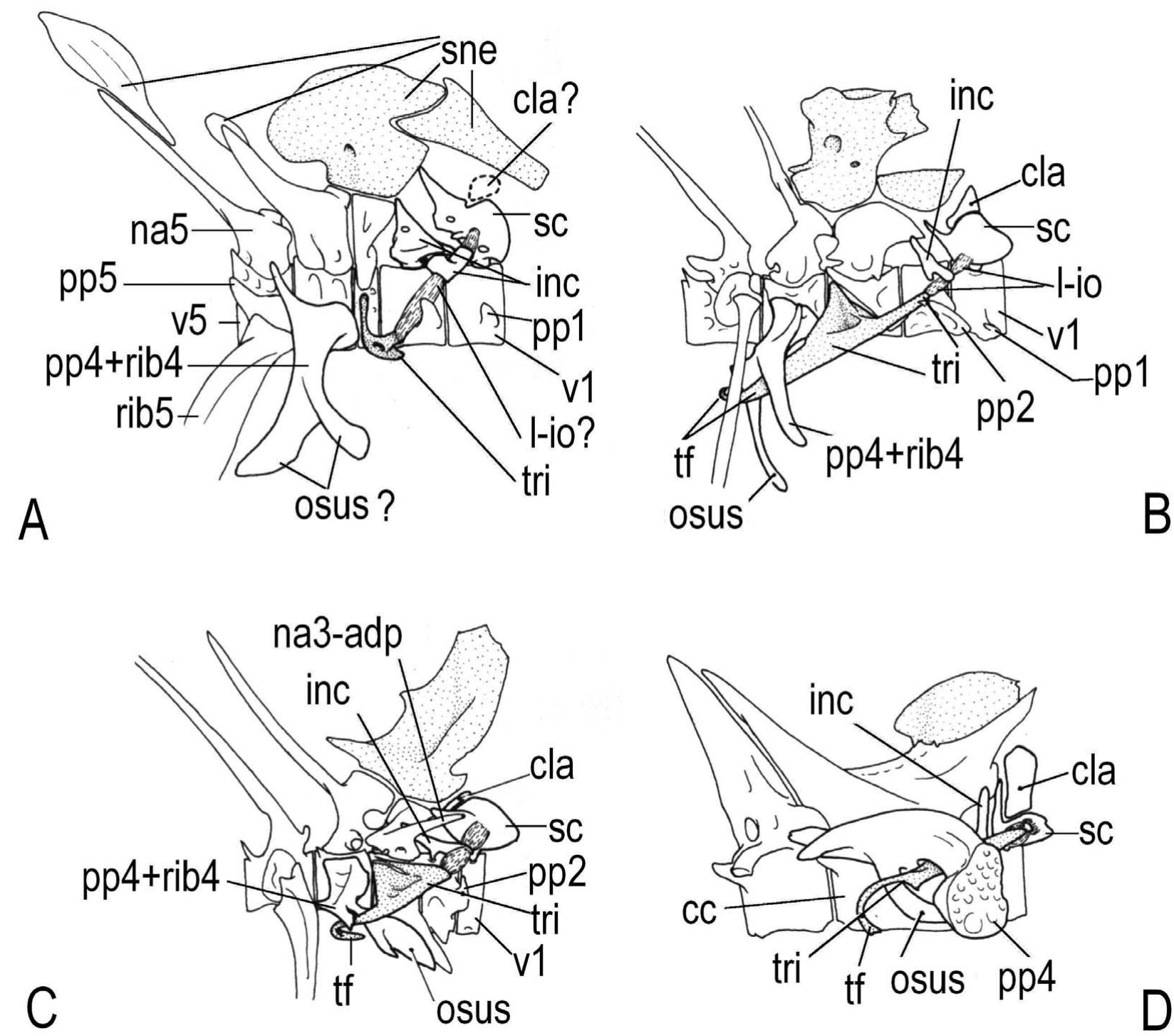

Fig. 4. Outline drawings of the Weberian ossicles in $\dagger$ Chanoides macropoma (A), the cypriniform Opsariichthys uncirostris (B), the characiform Xenocharax spilurus (C), and the siluriform Diplomystes papillosus (D) (modified from Patterson, 1984; the identity of the structures illustrated follows that used by the author of the original drawing). cc, complex centrum; cla, claustrum; inc, intercalarium; lio, interossicular ligament; na3-adp, anterodorsal process of neural arch 3; na5, neural arch 5; osus, os suspensorium; pp1, 2, 4, 5, parapophyses of free vertebrae 1,2, 4 and 5; rib4, 5, ribs of free vertebrae 4 and 5; sc, scaphium; sne, supraneurals; tf, transformator tripodis; tri, tripus; v1, v5, free vertebrae 1 and 5.

first arch like a structure of the vertebral column, lying between the back of the skull and the neural arch of the first free vertebra and not being associated with the centrum of this latter vertebra (Fig. 3A). Thus, as explained above, according to these authors the function of the claustrum is similar to that of the accessory neural arch: it forms a protective bony wall around the anterior portion of the neural canal, in the space between the back of the skull and the start of the neural arch series. The homology between the claustrum of extant otophysans and the accessory neural arch of teleosts such as clupeomorphs has also been considered to be likely by Chardon et al. Consequently, this now constitutes, in a certain way, the most accepted hypothesis for the origin of this ossicle. However, more detailed developmental, as well as palaeontological, data is clearly needed in order to test this hypothesis in the future. 


\section{Tripus}

Concerning the tripus, authors of developmental studies such as Rademarker et al. (1988), Vandewalle et al. (1990), Fukushima et al.; Ichiyanagi et al. (1993, 1996) argued that this ossicle develops exclusively from the parapophysis of the third free vertebra. Researchers such as Bamford, Rosen \& Greenwood; Grande \& Young (2004) defended that it develops ontogenetically from both the parapophysis and the rib of this vertebra (Fig.6). Other authors, e.g. Watson; Kulshrestha; Bogutskaia argued that part of this ossicle arises ontogenetically from the partial ossification of soft structures such as the swimbladder and/ or of the interossicular ligament. This latter hypothesis was recently supported by Chardon et al., who, based on a review of the literature and on a functional and structural analysis, defended that at least the characteristic posterior portion of the tripus of extant otophysans, i.e. the transformator tripodis, has originated by partial ossification of the swimbladder (Fig. 2C, 2D, 3B).

The palaeontological data obtained so far from basal otophysan fossils does not help to clarify if soft structures such as the interossicular ligament and/or the swimbladder might indeed have contributed for the formation of the tripus of extant otophysans. But Filleul \& Maisey's observations on $\dagger$ Santanichthys diasii strongly support the idea that both the parapophysis and the rib of the third free vertebra contributed for the formation of the tripus of extant otophysans. This because both these structures are clearly incorporated in the 'plesiomorphic' tripus of this species (see Fig. 5D). As written on the above discussion on the homologies of the intercalarium, future studies on the Weberian apparatus should pay special attention to the development of soft structures such as the interossicular ligament or the swimbladder, as well as to the connections between these and other Weberian structures.

\section{Os suspensorium}

Developmental studies such as Vandewalle et al. (1990), Fukushima et al.; Ichiyanagi et al. (1993, 1996) indicated that the os suspensorium develops from the parapophysis of the fourth free vertebra. However, researchers such as Sagemehl; Bamford defended that it develops from the rib, and not from the parapophysis, of this vertebra. Other authors, e.g. Rosen \& Greenwood, argued that it develops from both the parapophysis and rib of the fourth free vertebra (Fig. 6).

The os suspensorium is the Weberian structure that displays a greater morphological diversity in extant otophysans (see e.g. Fig. 4B, C, D). This structure does also seemingly display a considerable morphological diversity in basal otophysan fossils such as $\dagger$ Chanoides macropoma, $\dagger$ Chanoides chardoni, $†$ Lusitanichthys characiformis, $\dagger$ Lusitanichthys africanus and $\dagger$ Clupavus maroccanus (the os suspensorium was not found in the fossils of $\dagger$ Santanichthys diasii, so it is not clear if this bone was present, or not, in the fishes of this species; Figs. 4A, 5A, B, C). Some comparisons can be made between these fossils and extant otophysans. For example, in $\dagger$ Chanoides macropoma the compound structure formed by the rib and the parapophysis of the fourth free vertebra appears to be somewhat similar to the compound structure formed by these two elements in the extant cypriniform Opsariichthys uncirostris (Fig. 4A, B). However, no information is available on the presence and possible configuration of a suspensor ligament or on the swimbladder and its connections in the preserved specimens of $\dagger$ Chanoides macropoma (Patterson). Consequently, it is difficult to discern if in this species any of the two ventral arms of this compound structure formed by the rib and the parapophysis of the fourth free vertebra did have such connections to the tripus and/or to the swimbladder, asthe os suspensorium of Opsariichthys uncirostris has.

\section{Otocephalan phylogeny and the evolution of the Weberian apparatus}

Some authors suggested that the characteristic Weberian apparatus present in the extant members of the orders Cypriniformes, Characiformes, Gymnotiformes and Siluriformes may have been originated more than once (e.g. Gayet 1981, 1985, 1986a, 1986b; Gayet \& Chardon). This is because, according to them, some extant otophysans are more closely related to fossils with a 'plesiomorphic' Weberian apparatus such as $\dagger$ Lusitanichthys characiformis, $\dagger$ Chanoides macropoma or $\dagger$ Clupavus maroccanus than to some other extant otophysans. This hypothesis was however contradicted by Patterson, Fink et al. (1984), Fink \& Fink (1996) and Chardon et al., who suggested that such fossils were very likely phylogenetically basal to the four orders of extant otophysans. One of the main causes for this controversy was the fact that, until so far, discussions on the phylogenetic position of these fossils were focused on disarticulated analyses of a few specific features, and not on an explicit cladistic analysis including these fossils and representative extant otophysan taxa.

The cladogram shown in Figure 1, including not only representative extant otophysan taxa and the fossils $\dagger$ Chanoides macropoma, †Clupavus maroccanus, $\dagger$ Santanichthys diasii, and $\dagger$ Lusitanichthys characiformis, but also members of closely related groups such as gonorynchiforms, †Tischlingerichthys viohli and 

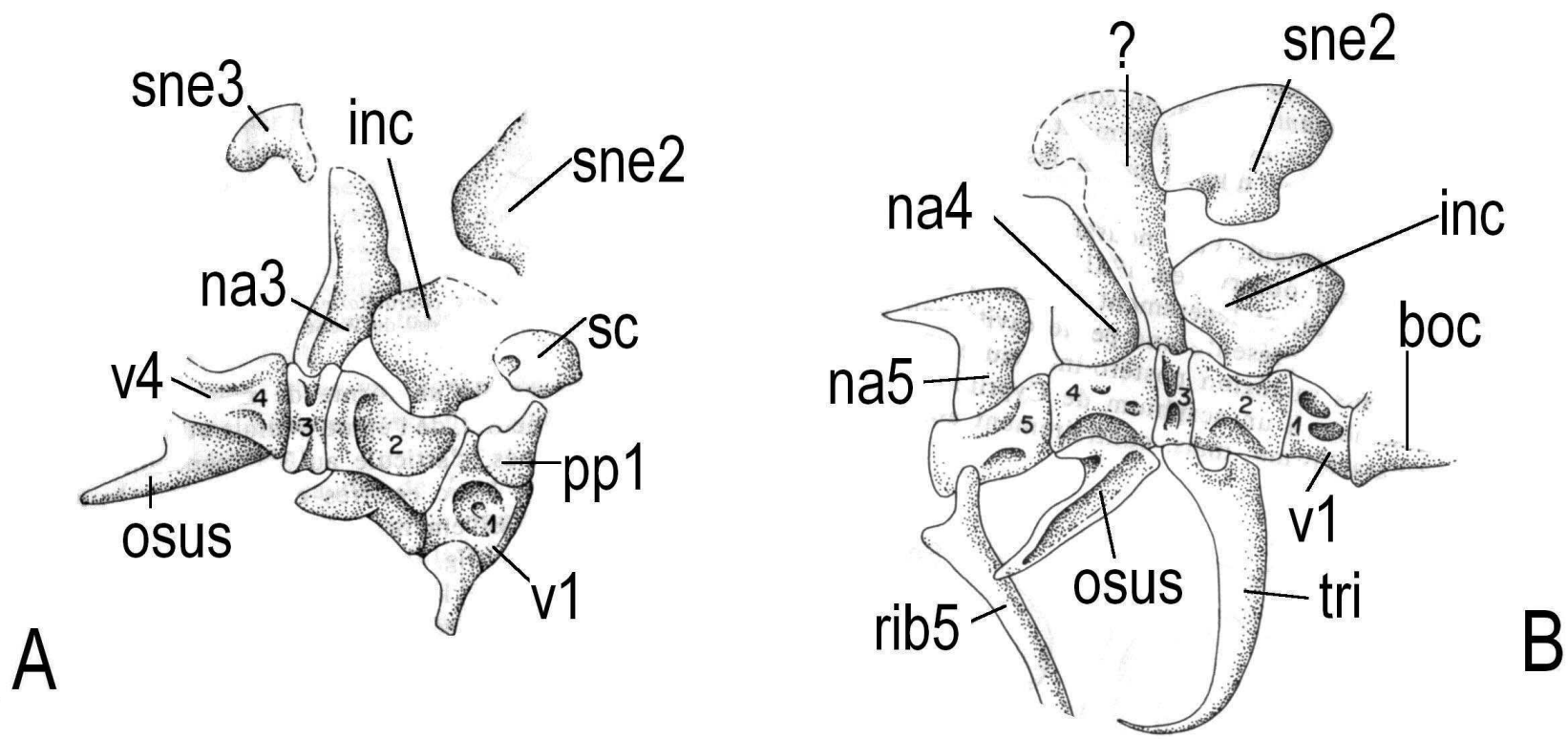

\section{inc(+na3?) sne}
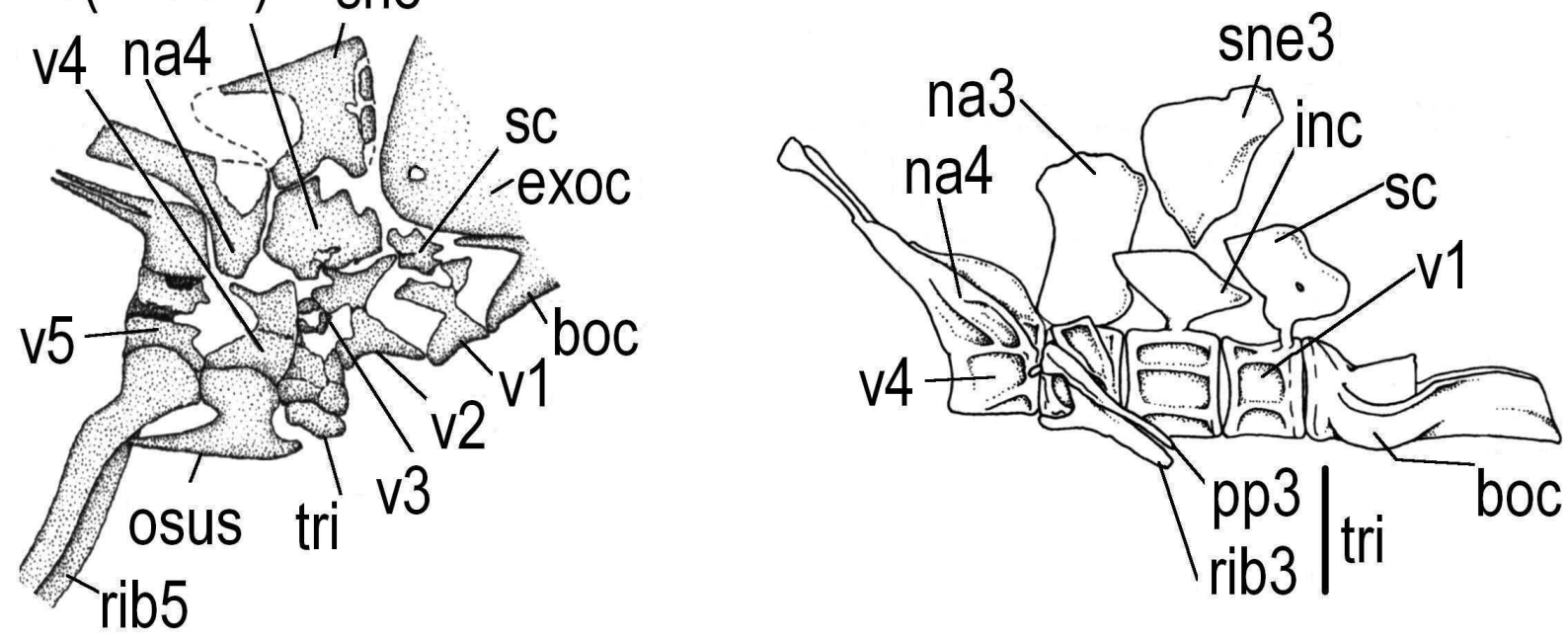

C

Fig. 5. Outline drawings of the Weberian ossicles in $\nmid$ Lusitanichthys characiformis $(\mathbf{A}, \mathbf{B}), \uparrow$ Clupavus maroccanus $(\mathbf{C})$, and $\dagger$ Santanichthys diasii (D) (modified from Gayet, 1985; Taverne, 1995; Filleul \& Maisey, 2004; the identity of the structures illustated follows that used by the authors of the original drawings). boc, basioccipital; exoc, exoccipital; inc, intercalarium; na3, na4, na5, neural arches 3, 4 and 5; osus, os suspensorium; pp1, 3, parapophyses of free vertebrae 1 and 3; rib3, 5, ribs of free vertebrae 3 and 5; sc, scaphium; sne, supraneural; sne2, 3, supraneurals 2, 3; tri, tripus; v1, v2, v3, v4, v5, free vertebrae 1, 2, 3, 4 and 5.

$\dagger$ Sorbininardus apuliensis as well as clupeomorphs, can therefore bring light to this controversy. According to the phylogenetic scenario shown in that figure, the fossils $\dagger$ Lusitanichthys characiformis, $\uparrow$ Chanoidesmacropoma and $\dagger$ Clupavus maroccanus appear, together with another fossil exhibiting a 'plesiomorphic' Weberian apparatus, $\dagger$ Santanichthys diasii, in a monophyletic unit that is the sister- group of the clade including the four extant otophysan orders. This thus seems to suggest that the characteristic Weberian apparatus of the members of these four orders appeared only once. A 'plesiomorphic' Weberian apparatus appeared in the clade including fossils such as †Chanoides macropoma, $\dagger$ Clupavus maroccanus, $\dagger$ Santanichthys diasii, and $\dagger$ Lusitanichthys characiformis plus the four extant otophysan 
orders, being then further modified in the characteristic, functional Weberian apparatus (e.g. Chardon et al.) of extant otophysans in the node leading to these four orders (Fig.1).

As noted above, the scaphia of fossils such as $\dagger$ Chanoides macropoma seem effectively more 'plesiomorphic' than those of extant otophysans, because they bear foramina for dorsal and ventral nerve roots (Fig. 4A; the vast majority of extant otophysans lack such foramina). The scaphia of $\dagger$ Lusitanichthys characiformis and $\dagger$ Clupavus maroccanus are not well preserved, and it is thus not clear if these ossicles presented, or not, such foramina, but their overall configuration seem also apparently less derived than that of extant otophysans, as noted by Patterson, Fink et al. (1984), Fink \& Fink (1996), and Chardon et al. The primary homology hypothesis (see e.g. De Pinna 1991; Diogo 2004a) stating that the scaphia of fossils such as $\dagger$ Lusitanichthys characiformis, $\dagger$ Clupavus maroccanus, $\dagger$ Chanoides macropoma and $\dagger$ Santanichthys diasii are less derived than those of extant otophysans is supported by the phylogenetic results of Diogo, 2007 cladistic analysis (Fig.1).

Patterson, Fink et al. (1984), Fink \& Fink (1996), and Chardon et al. also pointed out that the intercalaria of these fossils are apparently less derived than those of extant otophysans. For instance, contrary to what happens in the vast majority of extant otophysans, the intercalarium of $\dagger$ Chanoides macropoma exhibits, as does the scaphium of this species, foramina for dorsal and ventral nerve roots (Fig. 4A, compare with Fig. 4B, C, D). Such foramina were apparently not found in the intercalaria of $\dagger$ Lusitanichthys characiformis, $\dagger$ Clupavus maroccanus, and $\dagger$ Santanichthys diasii (Fig. 5). However, the intercalaria of these three latter species are effectively much larger than the intercalaria of most extant otophysans, and apparently lack the ascendens processus typical of these latter fishes (Fig. 5, compare with Fig. 4B, C, and D). The primary homology hypothesis stating that the intercalaria of $\dagger$ Lusitanichthys characiformis, $\dagger$ Clupavus maroccanus, $†$ Chanoides macropoma and $\dagger$ Santanichthys diasii are less derived than those of extant otophysans is also supported by the phylogenetic results of Diogo, 2007 cladistic analysis (Fig. 1).

Patterson, Fink et al. (1984), Fink \& Fink (1996), Taverne (1999), Chardon et al. and Taverne (2005) called the attention for some morphological differences between the tripus of $\dagger$ Lusitanichthys characiformis, $\dagger$ Clupavus maroccanus, $\uparrow$ Chanoides macropoma, $\dagger$ Chanoides chardoni and $\dagger$ Santanichthys diasii and that of extant otophysans. In $\dagger$ Chanoides macropoma, for instance, the tripus is seemingly much smaller than the characteristic tripus of extant otophysans (the tripus of $\dagger$ Chanoides chardoni is also relatively small, although it is not as small as that of $\dagger$ Chanoides macropoma: Taverne, 2005: fig. 12). Moreover, the tripus of $\dagger$ Chanoides macropoma and $\dagger$ Chanoides chardoni seemingly lacks a transformator tripodis; in $\dagger$ Chanoides macropoma most of the lateral portion of the tripus is situated anteriorly to its mesial portion contacting the third centrum (Fig. 4A, compare with Fig. 4B, C, D). However, it should be noted that Fink \& Fink (1996) stated that Patterson (unpublished results) found a structure similar to a transformator tripodis in some specimens of $\dagger$ Chanoides macropoma. Therefore, it is not clear whether $\dagger$ Chanoides macropoma has, or not, a transformator tripodis.

According to the reconstruction done by Filleul \& Maisey (Fig. 5D), the lateral portion of the tripus of $\dagger$ Santanichthys diasii is apparently situated mainly anteriorly to its mesial portion. This, again, is different to the characteristic condition found in extant otophysans (Fig. 5D, compare with Fig. 4B, C, D). Moreover, according to the same reconstruction, the parapophysis and rib of the third free vertebra integrating the tripus are still completely separated (Fig. 5D, compare with Fig. 4B, C, D; see discussion on homologies above).

Concerning $\dagger$ Lusitanichthys characiformis, the tripus shown in figure 23 of Gayet (1985) does seem to have a distal incurvation that somewhat resembles the characteristic transformator tripodis of extant otophysans (Fig. 5B). However, the tripus of the $\dagger$ Lusitanichthys characiformis specimens shown in figures 24 and 25 of Gayet (1985) is apparently very different from that shown in figure 23 of that same work, being seemingly much less modified from the plesiomorphic condition and lacking a distal incurvation. The tripus of $\dagger$ Lusitanichthys africanus is unknown (Cavin). As noted by Taverne (1995), the tripus of the $\dagger$ Clupavus maroccanus specimens analyzed by him is poorly preserved (Fig. 5C). However, from the figures provided in Taverne's (1995) work, it seems that the tripus of that species is also different from the characteristic tripus of extant otophysans, being apparently somewhat similar to a modified parapophysis of the third free vertebra as that found in derived clupeomorphs such as pristigasteroids (e.g. Grande \& De Pinna 2004). It should be noted that the phylogenetic results of Diogo, 2007 cladistic analysis (Fig.1) strongly suggest that the condition found in these derived clupeomorphs and in $\dagger$ Clupavus maroccanus is not homologous. They support, instead, the view of authors such as Patterson, Fink et al. (1984), Fink \& Fink (1996), Taverne $(1999,2005)$ and Chardon et al., according to which $\dagger$ Clupavus maroccanus, as well as $\dagger$ Lusitanichthys characiformis, $\dagger$ Chanoides macropoma, $†$ Chanoides chardoni and $†$ Santanichthys diasii, have a somewhat 'plesiomorphic' tripus that is less derived than that of extant otophysans. 


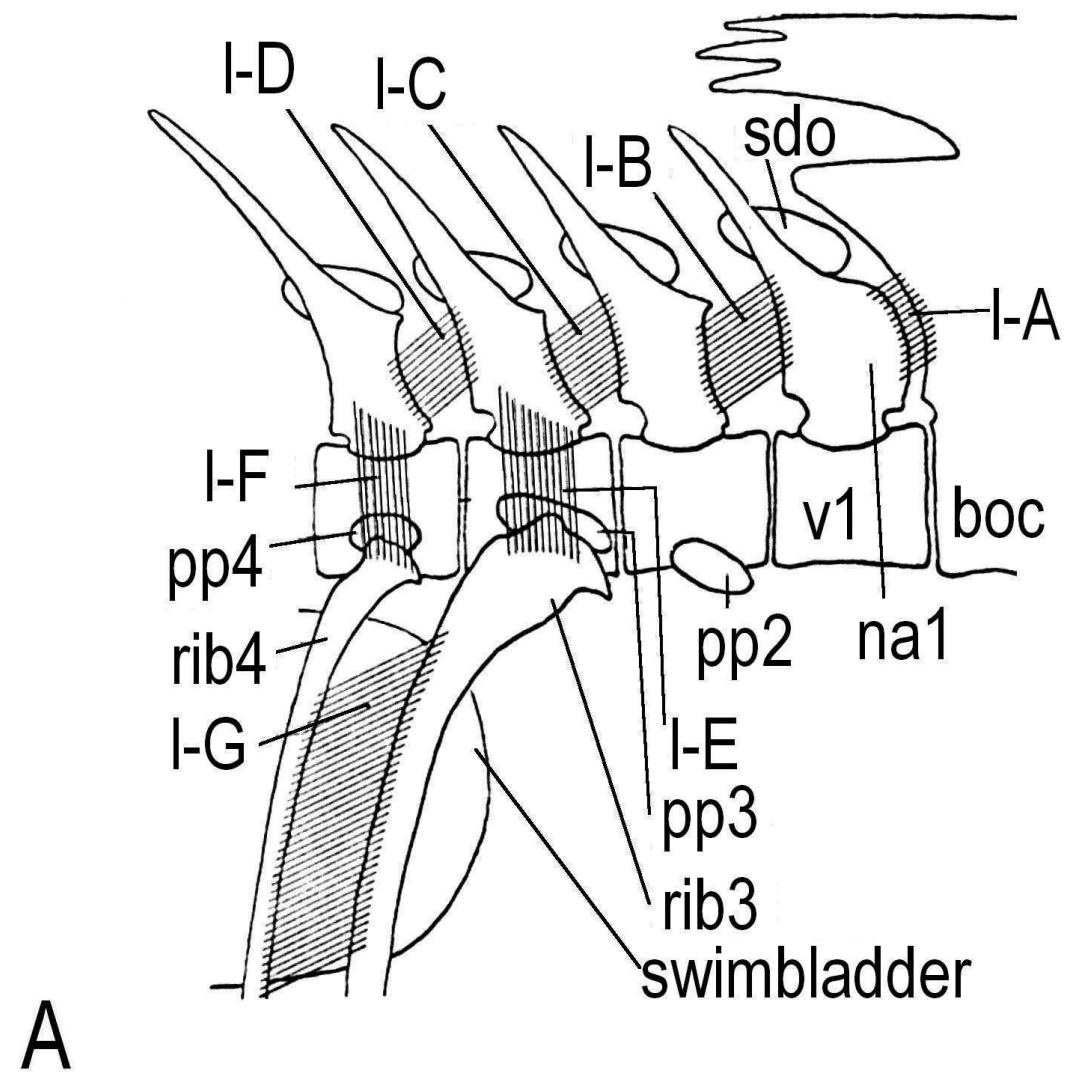

Fig. 6. Diagram to explain the Rosen and Greenwood's 1970 hypothesis concerning the homologies between the structures of the occipitocervical region of nonotophysans such as the gonorynchiform Chanos (A) and otophysans such as the characiform Brycon (B) (modified from Rosen and Greenwood, 1970; the identity of the structures illustated follows that used by the authors of the original drawing). boc, basioccipital; cla, claustrum; inc, intercalarium; l-A, B, C, D, E, F, G, ligaments A, B, C, D, E, F and $\mathrm{G}$; l-io, interossicular ligament; na1, neural arch 1; osus, os suspensorium; pp2, 3, 4, parapophyses of free vertebrae 2,3 and 4 ; rib3, 4, ribs of free vertebrae 3 and 4; sc, scaphium; sdo, supradorsal; $\mathbf{t f}$, transformator tripus; tri, tripus; $\mathbf{v 1}$, free vertebra 1 . 
The claustrum was apparently lacking in the specimens of $\dagger$ Chanoides macropoma, $\dagger$ Lusitanichthys characiformis, $\dagger$ Clupavus maroccanus, and $\dagger$ Santanichthys diasii (Figs. 4A, 5A, B, C, D). However, as noted by Patterson, Gayet (1981, 1985), Taverne (1995) and Filleul \& Maisey, in extant Otophysi this is often a very small bone (e.g. Fig. 4B, C), being inclusively missing in numerous fishes of this group, such as gymnotiforms and many siluriforms. According to these authors, the apparent absence of a claustrum in those four fossil species does probably not mean that this ossicle was effectively missing in all members of those species. As noted above, this view was supported by the apparent discovery, by Taverne (2005), of a well-developed claustrum in $†$ Chanoides chardoni.

The phylogenetic results of Diogo (2007) (see Fig. 1) corroborate the opinion of authors such as Patterson, Fink et al. (1984), Fink \& Fink (1996) and Chardon et al., according to which the os suspensorium found in e.g. $\dagger$ Chanoides macropoma, $\dagger$ Lusitanichthys characiformis and $\dagger$ Clupavus maroccanus is less derived than that found in extant otophysans. Interestingly, contrary to the configuration found in most extant otophysans, according to the drawings of Patterson, Gayet (1985) and Taverne (1995) the os suspensorium of $\dagger$ Chanoides macropoma, $\dagger$ Lusitanichthys characiformis and $\dagger$ Clupavus maroccanus does not form, together with the other ventral structures of the four free vertebra, a tunnel/bifurcation for the enclosing of part of the tripus (Figs. 4A, 5A, B, C, compare with Fig. 4B, C, D). It should however be stressed that Patterson apparently (unpublished results) found a transformator tripodis in $\dagger$ Chanoides macropoma (see above). Therefore, this latter structure might have passed in the pronounced ventrolateral bifurcation of the compound formed by the parapophysis and the rib of the fourth free vertebra of this species (Fig. 4A). As explained above, one should keep in mind that the os suspensorium of extant otophysans is somewhat diverse in shape, and, thus, that it difficult to define, in reality, what is the overall 'normal/usual' configuration of this bone within the members of the four extant otophysan orders (Fig. 4B, C, D).

At this point one important clarification, with crucial implications for the discussion on the evolution of the Weberian apparatus, needs to be made: when it is said, as was done above, that the 'true', functional Weberian apparatus found in extant otophysans appeared only once, this does not means that all the numerous individual features integrated in the functioning of this apparatus appeared at the same time. In fact, as noted by e.g. Rosen \& Greenwood; Fink \& Fink (1996), Chardon et al. and Grande \& De Pinna (2004), it is clear that many of the individual features that integrate the Weberian apparatus and many of the necessary requirements to allow the functionality of the whole apparatus in extant otophysans did not appear exclusively on the node leading to these latter fishes. For instance, the connection between the parapophyses and/or ribs of the first free vertebrae with the swimbladder, the constriction of the swimbladder into two chambers or the anterior most neural arch abutting the back of the skull are features also present in gonorynchiforms (Fig. 6A), and even in some clupeiforms such as the pristigasteroids (e.g. Rosen \& Greenwood; Grande \& Poyato-Ariza 1999; Grande \& De Pinna 2004). However, as stressed by Chardon et al. and Grande \& De Pinna (2004), one cannot state that the presence of such features in fishes such as gonorynchiforms and pristigasteroids necessarily means that these fishes have a functional Weberian apparatus as that of otophysans. Instead, these individual features should be seen as probable exaptations (e.g. Gould; Diogo 2004a), that is, as features that have likely been initially acquired for another reason, and that were only later integrated in the functioning of the Weberian apparatus.

As recently recognized by Grande \& Braun (2002); Chardon et al.; De Pinna \& Grande (2003) and Grande \& De Pinna (2004), in order to provide a more comprehensive and contextualized discussion on the origin and evolution of the various features involved in the functioning of the Weberian apparatus, one should therefore take into account the condition found in not only basal and extant otophysans, but also in other ostariophysans as well as in fishes such as clupeomorphs (Fig.1). In view of the phylogenetic scenario shown in Figure 1 , of the author's observations, and of a review of the literature available, it seems effectively possible to provide here an updated, phylogenetically based discussion on how may have been, in major lines, the evolution of these features. This discussion is given below, and is divided into three parts, which concern respectively the otocephalan clade, the ostariophysan clade and the otophysan clade.

\section{Otocephalan clade}

Some important features related to the peculiar configuration and the peculiar functioning of the Weberian apparatus of extant otophysans seemingly appeared in the node leading to otocephalans, i.e. leading to clupeomorphs plus ostariophysans (Fig. 1). These include, for instance, the posterior and medial position of the sacculi and lagenae otoliths and the presence of a silvery peritoneal tunic of the swimbladder covering at least the anterior portion of this bladder (e.g. Fink \& Fink, 1981; Chardon et al.; Grande \& De Pinna, 2004). Thus, plesiomorphic otocephalans seemingly already had at least some peculiar features that were later crucial for the formation and functioning of the Weberian apparatus of extant otophysans. However, one should keep in mind that the second feature listed above refer to soft structures and that, althoughthese structures seem effectively to be 
plesiomorphically present in extant clupeomorphs and in extant ostariophysans (Grande \& De Pinna, 2004), one cannot be completely sure if they were effectively also present in basal fossils of these groups, e.g. $\dagger$ Diplomystus dentatus or $\dagger$ Tischlingerichthys viohli (Fig.1). Consequently, unless the eventual discovery of well-preserved basal otocephalan, clupeomorph and/or ostariophysan fossils will allow to discern if such features were effectively present in these fossils, one should be particularly careful about considering them as synapomorphies of the Otocephala as a whole.

A feature that is also important for the formation of the Weberian apparatus as a whole, and that may also possibly constitute a synapomorphy of the Otocephala, is the attachment of the anterior pleural ribs to the swimbladder. Authors such as Rosen \& Greenwood; Fink \& Fink (1981, 1996) suggested that this feature is a synapomorphy of ostariophysans, since it is present in extant gonorynchiforms and in extant otophysans. However, as pointed out by Grande \& De Pinna (2004), in extant clupeiforms such as pristigasteroids and some engrauloids there is an attachment of the anterior ribs to the swimbladder that is apparently similar to that found in extant gonorynchiforms and otophysans. Since it is difficult to discern if such a configuration was present in basal clupeomorphs such as $\dagger$ Diplomystus dentatus and in ostariophysan fossils such as $\dagger$ Tischlingerichthys viohli and $\dagger$ Sorbininardus apuliensis, it is difficult to appraise if this configuration was plesiomorphically present in the Clupeomorpha (its absence in extant clupeiforms such as Denticeps being thus due to a secondary loss), and, therefore, in the Otocephala (see Fig.1).

Chardon \& Vandewalle (1997) and Chardon et al. suggested that the first otocephalans might also had another peculiar feature that was subsequently crucial for the formation of the Weberian ossicles: the presence of an anterior otophysic diverticula of the swimbladder penetrating the back of the skull and contacting the inner ear, as seen for example in many extant clupeiforms (Fig. 3). As explained above, according to these authors the interossicular ligament of the Weberian chain of otophysans was very likely originated from such swimbladder diverticula (Fig. 3). As an argument for supporting their hypothesis, they pointed out that a comparison between the fibers of the interossicular ligament and those of the tunica externa of the swimbladder reveal the same histological composition: both contain elastin and ichthyocoll, a special type I collagen which is usually absent in other ligaments. Therefore, they hypothesized that clupeiform-like diverticula transformed into the interossicular ligaments by loosing their internal endoderm-splanchnopleura sheet (Fig. 3 ). According to these authors, this sheet was probably inefficient in transporting gas (and pressure) instantaneously because the lumen of the diverticula was too narrow, while their external fibrous coating could transmit vibrations. Consequently, according to them, the 'functional part' of the Weberian ossicles would be the result of intraligamentous ossifications (Chardon et al.). Therefore, the neural arches 1 and 2 and the parapophysis of the third free vertebra "fused with the intraligamentous primordia later to form the complete ossicles in the same way as in ontogeny; their role seemingly being to sustain the ligament during lateral flexions of the anterior most backbone" (Chardon et al.).

According to e.g. Grande (1985) and Grande \& De Pinna (2004), the areas of thin inflated bone on the posteroventral region of the neurocranium of clupeomorph fossils such as $\dagger$ Diplomystus and $\dagger$ Armigatus seems to suggest that these fossils had prootic and pterotic bullae, thus indicating that these basal clupeomorph fossils had otophysic diverticula connecting the swimbladder to the inner ear. According to these authors, such a feature might therefore be plesiomorphic for clupeomorph fishes. If this is so, and if an origin of the interossicular ligament of the otophysan Weberian apparatus from the swimbladder diverticula were to be accepted (as proposed by Chardon et al.), one could hypothesize that such diverticula were plesiomorphically present in otocephalans and secondarily lost in gonorynchiforms. Such a secondary loss in gonorynchiforms could possibly be explained by the fact that, from the plesiomorphic condition found in ostariophysans, otophysans and gonorynchiforms seem effectively to have followed two different evolutionary pathways regarding the connection between their swimbladder and the posterior region of the skull (see below).

However, if one accepts Chardon et al's. origin of the Weberian interossicular ligament from anterior diverticula of the swimbladder, one could as well postulate an alternative scenario, which is perhaps even more likely than that mentioned above: that the swimbladder diverticula that originated this ligament are not homologous with those present in clupeomorphs. That is, it might well be that both otophysans and clupeomorphs have independently acquired such otophysic diverticula connecting the swimbladder to the inner ear. Such a scenario is not unlikely. As recently summarized by Braun \& Grande (2002), anterior diverticula of the swimbladder have been independently acquired several times within teleosts. They are for example present in numerous non-otocephalan teleost families such as Notopteridae, Mormyridae, Hiodontidae, Megalopidae, Gadidae, Holocentridae and Cichlidae. Moreover, one should keep in mind that within extant otocephalans such anterior extensions of the swimbladder are present not only in clupeiforms, but also in some otophysans. For example, the pimelodid catfish Calophysus macropterus exhibits a modified swimbladder with two well-defined, anterior diverticula extending 
anteriorly under the prootic, near to the level of the utriculus. These diverticula lie ventral to the Weberian ossicles and are almost parallel to the chain formed by these ossicles (Chardon, 1968: fig 71). As swimbladder diverticula have been acquired various times within the Teleostei, one cannot exclude the hypothesis that anterior diverticula such as those found in Calophysus macropterus or those found in clupeomorphs might have been acquired in the node leading to otophysans and then been transformed in the Weberian ossicular ligament.

In fact, as noted above, the first otocephalans seemingly had some peculiar features that may had facilitated, later in evolution, the evolution of an otophysic connection in at least some of their descendents. Thus, starting from ancestors already sharing these features, it is conceivable that different otocephalan groups such as clupeomorphs and otophysans might have acquired, by parallel evolution (see e.g. Gould; Diogo, 2004a, 2005), anterior swimbladder diverticula allowing the establishment of such an otophysic connection.

Chardon et al.'s hypothesis of an origin of the interossicular ligament of the Weberian apparatus from otophysic diverticula, illustrated in Figure 3, is in opposition to the hypothesis advanced by authors such as Rosen \& Greenwood, illustrated in Figure 6. According to this latter hypothesis, the Weberian interossicular ligament was derived from a combination of the ligaments joining the parapophysis/rib of the third free vertebra and the third neural arch, joining this neural arch to the second neural arch, and joining this latter neural arch to the first neural arch. However, there are three main difficulties with this hypothesis. Firstly, both the interossicular ligament and the tunica externa of the swimbladder contain elastin and ichthyocoll, a special type I collagen which is usually absent in other ligaments (see above). Secondly, in all the numerous otocephalan fishes I have dissected so far, I never found a well-defined ligament joining the parapophysis and/or rib of the third free vertebra and the third neural arch as that postulated in Rosen \& Greenwood hypothesis. Thirdly, if such a ligament was indeed present in the first ostariophysans, both this ligament and the ligament joining the third neural arch to the second neural arch should have suffered an evolutionary loss of their connections to the third neural arch in order to give rise to the interossicular ligament of otophysans (see Fig. 6). This is not theoretically impossible. However, the recent advances in the fields of evolutionary developmental biology and vertebrate phylogeny have pointed out that such changes in the attaching points of ligaments and/or tendons are clearly not so usual in evolution as previously assumed (e.g. Köntges \& Lumsden, 1996; Shoshani et al., 1996; Collard \& Wood, 2000; Gibbs et al., 2000, 2002; Diogo, 2004a; 2000b; Graham, 2005).
One should also take into account another possibility for the origin of the interossicular ligament of the Weberian apparatus: an origin from a tendon and/or an unossified intermuscular bone. As stressed by Patterson \& Jonhson (1995), the importance of intermuscular bones has been often neglected in discussions on the evolution and homologies of teleosts. And the study of muscles and ligaments has, unfortunately, deserved less attention in teleostean literature than that given to the study of bones (e.g. Diogo, 2004a; 2000b). As noted by Patterson \& Jonhson; Chardon et al.; Diogo (2004a), among the works done so far on the comparative anatomy and development of the postcranial region of otocephalans, very few have focused on the configuration of the muscles and ligaments of this region.

Two arguments can be given in order to support a possible origin of the Weberian interossicular ligament of otophysans from a tendon and/or an unossified intermuscular bone. The first is that, as noted by Patterson \& Jonhson, intermuscular bones are usually present in the postcranial region of clupeomorph and gonorynchiform fishes. Such structures were thus seemingly present in the first ostariophysans. And they are, in fact, present in some basal otophysan fossils such as $\dagger$ Chanoides macropoma and $\dagger$ Lusitanichthys characiformis (e.g. Patterson; Gayet, 1981, 1985). Moreover, in some adult otocephalans I have dissected, such as the clupeiform Ilisha and the gonorynchiform Gonorynchus, I did find some long, thin tendons running from the parapophyses and/or ribs of the first free vertebrae to the posterior region of the skull (which are supposedly the remaining of small muscles connecting the vertebrae to the cranium: Diogo, 2007).

\section{Ostariophysan clade}

The paragraphs above stressed the fact that some important features later integrated in the functioning of the Weberian apparatus of otophysans, such as the posteromedian position of the sacculi and lagenae otoliths and the presence of a silvery peritoneal tunic of the swimbladder, but also the presence of postcranial intermuscular bones and the attachment of the anterior ribs to the swimbladder, might actually have already been present in the first otocephalans. However, as might be expected, the configuration of the anterior free vertebrae and related structures of these first Otocephala was very likely not as similar to the configuration found in Otophysi as that found in the first Ostariophysi (sensu lato, that is, the clade including otophysans, gonorynchiforms and also fossils such as $\dagger$ Tischlingerichthys viohli and $\dagger$ Sorbininardus apuliensis: Fig. 1).

As pointed out by e.g. Rosen \& Greenwood; Fink \& Fink (1981, 1996), and Grande \& de Pinna (2004), in the node 
leading to the Ostariophysi there was an acquisition of a large number of peculiar, derived features that were subsequently crucial for the formation and functioning of the Weberian apparatus. The marked enlargement of the anterior neural arches is an example of these peculiar features (e.g. Figs. 4, 5, 6). According to Rosen \& Greenwood; Fink \& Fink (1981, 1996) the attachment of the first pleural ribs to the swimbladder might be another example, since such an attachment is present in extant gonorynchiforms and extant otophysans. However, as explained above, it is not possible to discern this feature in fossils; consequently one cannot be sure whether this feature does constitute, or not, a synapomorphy of a possible group gonorynchiforms + otophysans, of a group gonorynchiforms + otophysans + $\dagger$ Sorbininardus apuliensis, of these latter three groups plus $\dagger$ Tischlingerichthys viohli, or even of the Otocephala as a whole (Fig.1). Still another feature that was perhaps acquired in the node leading to the Ostariophysi is the enlargement of the anterior supraneurals. Within this clade, these supraneurals are usually enlarged in the Gonorynchoidei and in the Otophysi, as well as in the fossil †Sorbininardus apuliensis. Thus, according to the phylogenetic scenario of Figure 1, the first members of the group including all ostariophysans except $\dagger$ Tischlingerichthys viohli had, very likely, enlarged anterior supraneurals. However, since the anterior supraneurals of the fossil specimens of $\uparrow$ Tischlingerichthys viohli could not be observed (Arratia, 1997), it is not clear whether the enlargement of the anterior supraneurals is a synapomorphy of the whole Ostariophysi, or, instead, of ostariophysans excepting this latter fossil species.

It should be noted that some derived clupeomorphs such as pristigasteroids and engrauloids, e.g. Thryssa and Coilia, also present an enlargement of the anterior supraneurals and/or of the anterior neural arches (e.g. De Pinna \& Grande; Grande \& De Pinna, 2004; Diogo, 2007). However, this is not the case in more plesiomorphic clupeiforms such as Denticeps and in basal clupeomorphs such as $\dagger$ Diplomystus (Fig. 1; e.g. Grande; Grande \& De Pinna, 2004; Diogo, 2007). According to the phylogenetic scenario of Figure 1 these similarities between the condition found in some derived clupeomorphs and that found in ostariophysans is therefore probably due to homoplasy.

Grande \& De Pinna (2004) suggested that the shortening of the centra of the first three free vertebrae might be a synapomorphy of ostariophysans. But if one takes into fossils such as $\dagger$ Tischlingerichthys viohli and $\uparrow$ Sorbininardus apuliensis, this is not so clear. In $†$ Tischlingerichthys viohli, which is seemingly the most basal ostariophysan discovered so far (Arratia; Fig.1), the total length of the centra of the first three free vertebrae is not lesser than the total length of the centra of the free vertebrae 4, 5 and 6, for example (e.g. Arratia: fig. 65). In $†$ Sorbininardus apuliensis, the length of the centra of the first three free vertebra is unknown (Taverne, 1999). If one takes into account these fossils, one cannot say that the shortening of the centra of the first three free vertebrae constitutes an unambiguous synapomorphy of the Ostariophysi.

From the first ostariophysans, two main different evolutionary pathways seem to have been followed in the two major ostariophysan groups, i.e. in gonorynchiforms and in otophysans, respectively. In gonorynchiforms, there is a somewhat mobile type of connection between the swimbladder and the back of the skull (Rosen \& Greenwood). The details of this connection were well described by Rosen \& Greenwood, and will thus be only briefly summarized here. As in otophysans, in gonorynchiforms there is usually an attachment between the swimbladder and the ribs of the third and fourth free vertebrae (Fig. 6). However, although in gonorynchiforms the rib of the third free vertebra is usually enlarged relatively to the ribs of the following vertebrae (Fig. 6A), this rib is not as highly modified as in otophysans, and is not integrated in the peculiar Weberian apparatus of these latter fishes (see Fig. 6B). Instead, as noted by Rosen \& Greenwood (Fig.5), in gonorynchiforms this rib is usually deeply associated, via ligaments, muscles, and/or connective tissue, to the pectoral girdle and to well-developed, highly mobile cephalic ribs anteriorly abutting bones of the posteroventral region of the skull, near to the level of the inner ear, such as the basioccipital and/or exoccipital. A careful dissection of the postcranial region of gonorynchiforms has shown that by provoking artificial movements of the external layer of the swimbladder the somewhat mobile rib of the third free vertebra does effectively move, and this in turn does provoke a corresponding movement of the dorsolateral surface of the pectoral girdle and of the cephalic ribs (Diogo, 2007; this work).

However, as pointed out by e.g. Chardon et al., since the anterior portions of the cephalic ribs do not really penetrate any kind of opening/tunnel of the neurocranium allowing them to directly contact with the structures of the inner ear, it does not seem that the movements of these cephalic ribs could be efficiently transmitted to the inner ear. That is why I agree that the indirect connection between the swimbladder and the bones of the posteroventral surface of the neurocranium in gonorynchiforms hardly constitutes a 'true', functionally efficient otophysic connection between the swimbladder and the inner ear. In fact, such an indirect connection between the swimbladder and the bones of the posteroventral region of the neurocranium is also seen in otocephalan fishes other than gonorynchiforms, as e.g. in derived clupeomorphs such as the pristigasteroid Ilisha and the engrauloid Thryssa (Diogo, 2007; this work). For instance, in members of the genus Ilisha the rib of the third free vertebra is a somewhat modified, rather 
mobile structure attached to the swimbladder, as in gonorynchiforms (Fig.6A). Also, as in many gonorynchiforms, there are numerous intermuscular bones, muscles and ligaments in the postcranial region, which may effectively establish an indirect connection between this rib and the back of the skull. Moreover, the lateral surface of the rib of the third free vertebra is deeply associated with the also rather mobile dorsolateral portion of the pectoral girdle. This latter is, in turn, associated to the back of the skull by two strong, thick ligaments: the Baudelot's ligament attaches anteriorly on the first free vertebra, which is in contact with the basioccipital; the 'posttemporal-intercalar' ligament attaches anteriorly on the intercalar, which is a small bone situated on the back of the neurocranium (this work).

As explained above, clupeiforms have a functional otophysic connection between the inner ear and the swimbladder, realized by the anterior extensions of this bladder (Fig. 3A). Thus, derived clupeiforms such as Ilisha and Thryssa have: 1) a direct connection between the swimbladder and the inner ear, which according to authors such as Chardon et al. could have originated the Weberian connection between the swimbladder and the inner ear of otophysans; and 2) a indirect connection between the swimbladder and the back of the skull through connective tissue, tendons, intermuscular bones and/or the pectoral girdle, similar to that found in gonorynchiforms. As in gonorynchiforms, this latter indirect connection hardly seems to constitute a functional, efficient system allowing the inner ear to detect the changes of volume of the swimbladder. Such an indirect connection between the swimbladder and the back of the skull found homoplasically in gonorynchiforms and in some derived clupeiforms can thus seemingly be interpreted as an anatomical consequence possibly related to the functioning of other systems (e.g. the movements of the pectoral girdle), or, less likely, as part of a system related to an unknown function.

\section{Otophysan clade}

The evolutionary pathway followed by otophysans was quite different from that followed by gonorynchiforms. Contrary to extant gonorynchiforms, extant otophysans do have a direct, functional otophysic connection between the swimbladder as the inner ear, as described above (Figs. 2, 3D, 4B, C, D, 6B, compare with Fig. 6A).

Some of the most significant morphological transformations that have lead to the Weberian apparatus of extant otophysans, and that differentiate the condition found in these fishes from that found in gonorynchiforms, were seemingly acquired in the node leading to the clade including cypriniforms, characiforms, gymnotiforms, characiforms and fossils such as $\dagger$ Clupavus maroccanus, $\dagger$ Santanichthys diasii, $\dagger$ Chanoides macropoma, and $\dagger$ Lusitanichthys characiformis (Fig. 1). In fact, these fossils do already exhibit a 'plesiomorphic' tripus, a 'plesiomorphic' os suspensorium, a 'plesiomorphic' intercalarium and a 'plesiomorphic' scaphium (Figs. 4A, 5; see above). Fink \& Fink (1981; 1996) suggested that features such as the presence of the claustrum and the presence of a sinus impar are otophysan synapomorphies. However, since the data available does not allow to discern if both these features were, or not, present in fossils such as $\dagger$ Clupavus maroccanus, $\dagger$ Santanichthys diasii, $\uparrow$ Chanoides macropoma, and $\uparrow$ Lusitanichthys characiformis, one cannot discern whether these features are synapomorphies of the Otophysi as a whole or of the clade including only the four extant otophysan orders (Fig.1).

As explained above, although fossils such as $\dagger$ Clupavus maroccanus, $\dagger$ Santanichthys diasii, $\dagger$ Chanoides macropoma, and $\dagger$ Lusitanichthys characiformis already had 'plesiomorphic' Weberian structures such as the tripus, scaphium, intercalarium and os suspensorium, there are major differences concerning the configuration of these ossicles in those fossils and in extant otophysans. For instance, contrary to the condition seemingly found in e.g. $\dagger$ Clupavus maroccanus (Fig. 5C), in extant otophysans the tripus is a rather mobile element with a rather thin articulation with the centrum of the third free vertebra (Fig. 4B, C, D). Also, contrary to some of these fossils, as e.g. $\dagger$ Santanichthys diasii and $\dagger$ Lusitanichthys characiformis (Fig. 5B, D), in extant otophysans part of the tripus is seemingly enclosed in a tunnel/bifurcation formed by the os suspensorium and the other ventral elements of the fourth free vertebra (Fig. 4B, C, D). And, contrary to some of these fossils, as e.g. $\dagger$ Chanoides macropoma (Fig. 4A), in the vast majority of extant otophysans the scaphium and intercalarium do not have foramina for dorsal and ventral nerve roots (Fig. 4A).

A more detailed and complete list of the anatomical differences between the Weberian ossicles of these fossils and those of extant otophysans is given above. What is important to stress here is that, contrary to the hypothesis advanced by authors such as Gayet (1981, 1985, 1986a, 1986b), the phylogenetic scenario shown in Figure 1 supports the claim that the characteristic Weberian apparatus found in the members of the four extant otophysan orders was originated only once. Gayet (1981, 1985, 1986a, 1986b) defended that this was not the case because, according to her, some extant otophysans were very likely more closely related to fossils such as †Clupavus maroccanus and $\dagger$ Lusitanichthys characiformis than to other extant otophysans. However, the results of Diogo's 2007 cladistic analysis (Fig. 1) strongly contradict this latter phylogenetic hypothesis. Those results support a single origin of a 
'plesiomorphic' Weberian apparatus, as that found in fossils such as †Clupavus maroccanus, †Santanichthys diasii, $\dagger$ Chanoides macropoma, and $†$ Lusitanichthys characiformis (in the node leading to these fossils plus the extant otophysans) and a single origin of the characteristic Weberian apparatus of extant otophysans (in the node leading to the four extant otophysan orders: Fig.1) (see above).

\section{CONCLUSIONS}

It is hoped that, by complementing the author's observations and review of the literature with the results of an extensive cladistic analysis including not only several extant otocephalans but also fossils such as †Clupavus maroccanus, $\uparrow$ Santanichthys diasii, $\uparrow$ Chanoides macropoma, and $\dagger$ Lusitanichthys characiformis, the discussion provided here can help to clarify the origin, evolution and homologies of the Weberian apparatus. The complex Weberian apparatus of otophysans seems, in fact, to be the outcome of a functional integration of features acquired in basal otocephalans and in basal ostariophysans, which were very likely not directly related with the functioning of this apparatus, and of features acquired in the nodes leading to the Otophysi and to the clade including the four extant otophysan orders, which could well have been the result of a selection directly related to the functioning of this apparatus. This, of course, is just a scientific hypothesis, which should be, and hopefully will be, tested in future studies. There are, in fact, interesting issues that should be addressed in future works in order to shed further light on the origin, evolution and functioning of the Weberian apparatus. For instance, special attention should be paid to the development and comparative anatomy of the various muscles and ligaments associated with the anterior vertebrae in otocephalans, to the histological and mechanical properties of the tunica externa and its fibers, to the ontogeny of the ossicles, interossicular ligament and surrounding structures of the Weberian apparatus of otophysans and to the hydrostatic pressure sensitivity of the otophysan swimbladder and the possible transmission of that information through the Weberian ossicles to the labyrinths. And, hopefully, if this will be possible, to the configuration of new fossil Weberian apparatuses. It is precisely hoped that this work may stimulate, and pave the way for, such future works on one of the most puzzling and remarkable structural complexes of Vertebrates, the Weberian apparatus.

\section{ACKNOWLEDGEMENTS}

I would like to thank J. Snoeks, E. Vreven, and the late G.G. Teugels (Musée Royal de l'Afrique Centrale), P. Laleyé (Université Nationale du Bénin), R. Vari, J. Williams and S. Jewett (National Museum of Natural History), T. Grande (Field Museum of Natural History), D. Catania (California Academy of Sciences), M. Stiassny (American Museum of Natural History), Mark Sabad and J. Lundberg (Academy of Natural Sciences of Philadelphia), L. Page and M. Retzer (Illinois Natural History Survey) and P. Pruvost and G. Duhamel (Museum National d'Histoire Naturelle) for kindly providing a large part of the specimens analyzed for this study. I would also like to acknowledge P. Vandewalle, I. Doadrio, Z. Peng, S. Weitzman, T. Abreu, A. Zanata, F. Meunier, S. He, D. Adriaens, F. Wagemans, C. Oliveira, E. Parmentier, M.M. de Pinna, P. Skelton, F.J. Poyato-Ariza, H. Gebhardt, M. Ebach, A. Wyss, J. Waters, B. Perez-Moreno, G. Cuny, A. Choudhury, M. Vences, S.H. Weitzman, L. Cavin, F. Santini, J.C. Briggs, L.M. Gahagan, S. Hughes, M. Gayet, J. AlvesGomes, G. Lecointre, M. Chardon, P. Vandewalle, C. Borden, and many other colleagues for their helpful advice and assistance and for their discussions on teleostean comparative anatomy, functional morphology, phylogeny and/or evolution.

DIOGO, R. Origen, evolución y homologías del aparato weberiano: un nuevo acercamiento. Int. J. Morphol., 27(2):333-354, 2009.

RESUMEN: El aparato weberiano es esencialmente un dispositivo mecánico que mejora la audición, consiste en una doble cadena de osículos que unen la cámara de aire al oído interno. A pesar de ser uno de los sistemas complejos más notables de peces teleósteos y objeto de varios estudios comparativos, de desarrollo y funcionales, todavía hay mucha controversia sobre el origen, evolución y homologías de las estructuras que forman este aparato. En este trabajo se proporciona una nueva visión sobre estos temas, que tiene en cuenta los resultados de los últimos trabajos sobre la anatomía comparada, paleontología y la ontogenia, así como de un reciente análisis filogenético amplio que incluyen no sólo numerosos otocéfalos Otofisios y no Otofisios existentes, sino también fósiles Ostariofisios como Chanoides macropoma, Clupavus maroccanus, Santanichthys diasii, Lusitanichthys characiformis, Sorbininardus apuliensis y Tischlingerichthys viohli. Según las pruebas disponibles, el aparato weberiano de Otofisios parece ser el resultado de una integración funcional de las características adquiridas en otocéfalos basales y en ostariofisios basales, los cuales muy probablemente no estén directamente relacionados en el funcionamiento de este aparato, y las características adquiridas en los nodos que condujeron a los Otofisios y al clade incluyendo las cuatro órdenes existentes otofisios, que bien podrían haber sido el resultado de una selección directamente relacionada con el funcionamiento del aparato.

PALABRAS CLAVE: Evolución; Anatomía funcional; Ostariofisios; Otocefalos; Otofisios; Filogenia; Teleosteos; Aparato weberiano. 


\section{REFERENCES}

Alexander, R. McN. The physical properties of the swimbladders of some South American Cypriniformes. J. Exp. Biol., 38:40310, 1961a.

Alexander, R. McN. The structure of the Weberian apparatus in the Cyprini. Proc. Zool. Soc. Lond., 139:451-73, 1961 b.

Alexander, R. McN. The evolution of the Weberian apparatus in the Cobitidae. Proc. Zool. Soc. Lond., 143:177-90, 1964a.

Alexander, R. McN. The structure of the Weberian apparatus in the Siluri. Proc. Zool. Soc. Lond., 142:419-40, 1964 b.

Alexander, R. McN. Structure and function in catfish. J. Zool. (Lond.), 148:88-152, 1965.

Arratia, G. Basal teleosts and teleostean phylogeny. Paleo. Ichthyologica, 7:5-168, 1997.

Bamford, T. W. Cranial development of Galeichthys felis. Proc. Zool. Soc. Lond., 118:364-91, 1948.

Bogutskaia, H. G. Development of the Weberian apparatus during ontogeny of some species of Cyprinidae. J. Ichthyol., 31:36372, 1991.

Bridge, T. W. \& Haddon, A. C. Contributions to the anatomy of fishes: II The air- bladder and Weberian ossicles in the siluroid fishes. Phil. Trans. Roy. Soc. Lond., 184:65-333, 1894.

Butler, J. Development of the Weberian apparatus of catostomid fish. Proc. Iowa Acad. Sci., 67:532-43, 1960.

Cavin, L. A new Clupavidae (Teleostei, Ostariophysi) from the Cenomanian of Daoura (Morocco). C. R. Acad. Paris, 329(9):689-95, 1999.

Chardon, M. Anatomie comparée de l'appareil de Weber et des structures connexes chez les Siluriformes. Ann. Mus. R. Afr. Centr., 169:1-273, 1968.

Chardon, M., Parmentier, E. \& Vandewalle, P. Morphology, development and evolution of the Weberian apparatus in catfish. In Arratia, G.; Kappor, B. G.; Chardon, M. \& Diogo, eds. Catfishes. Enfield, Science Publishers, 2003. pp. 71-120.

Chranilov, N. S. Beiträge zur Kenntniss der Weber'schen Apparates bei Cypriniformes. Zool. Jb. Anat., 49:501-97, 1927.

Chranilov, N. S. Beiträge zur Kenntniss der Weber'schen Apparatus bei Siluroidea. Zool. Jb. Anat., 51:323-462, 1929.
Coburn, M. M. \& Futey, L. M. The ontogeny of supraneurals and neural arches in the cypriniform Weberian apparatus (Teleostei Ostariophysi). Zool. J. Linn. Soc., 116:333-46, 1996.

Coburn, M. M. \& Grubach, P. G. Ontogeny of the armored catfish Corydoras paleatus (Siluriformes: Callichthyidae). Copeia 1998:301-11, 1998.

Coburn, M. M. \& Chai, P. The development of the anterior vertebrae in Chanos chanos (Ostariophysi: Gonorynchiformes). Copeia, 2003:175-180, 2003.

Collard, M. \& Wood, B. How reliable are human phylogenetic hypotheses? Proc. Natl. Acad. Sci. US, 97:5003-6, 2000.

De la Hoz, E. \& Chardon, M. Skeleton, muscles, ligaments and swim-bladder of a gymnotid fish, Sternopygus macrurus Bloch \& Schneider (Ostariophysi: Gymnotoidei). Bull. Soc. R. Sci. Liège, 53:9-53, 1984.

De Pinna, M. C. C. Concepts and tests of homology in the cladistic paradigm. Cladistic,s 7:367-94, 1991.

De Pinna, M. C. C. \& Grande, T. Ontogeny of the accessory neural arch in pristigasteroid clupeomorphs and its bearing on the homology of the otophysan claustrum (Teleostei). Copeia, 2003:938-845, 2003.

Diogo, R. Morphological evolution, aptations, homoplasies, constraints, and evolutionary trends: catfishes as a case study on general phylogeny and macroevolution. Enfield, Science Publishers, 2004a.

Diogo, R. Muscles versus bones: catfishes as a case study for an analysis on the contribution of myological and osteological structures in phylogenetic reconstructions. Anim. Biol., 54:373-91, 2004b.

Diogo, R. Evolutionary convergences and parallelisms: their theoretical differences and the difficulty of discriminating them in a practical phylogenetic context. Biol. Philos., 20:73544, 2005.

Diogo, R. On the origin and evolution of higher-clades: osteology, myology, phylogeny and macroevolution of bony fishes and the rise of tetrapods. Enfield, Science Publishers, 2007.

Filleul, A. \& Maisey, J. G. Redescription of Santanichthys diasii (Otophysi, Characiformes) from the Albian of the Santana formation and comments on its implications for Otophysan relationships. Am. Mus. Novit., 3455:1-21, 2004.

Fink, S. V. \& Fink, W. L. Interrelationships of the ostariophysan fishes. Zool. J. Linn. Soc. (Lond.), 72:297-353, 1981.

Fink, S. V. \& Fink, W. L. Interrelationships of ostariophysan fishes 
(Teleostei). In Stiassny, M. L. J., Parenti, L. R. \& Johnson, G. D. eds. Interrelationships of Fishes. New York, Academic Press, 1996. pp. 209-49.

Fink, S. V.; Greenwood, P. H. \& Fink, W. A critique of recent works on fossil ostariophysan fishes. Copeia, 4:1033-41, 1984.

Franz, G. Über den Reflex des Gaspuckens bei Fischen und die Funktion des Weberschen Apparates. Z. vergl. Physiol. 25:193-200, 1937.

Fukushima, M., Kohno, H., Fujita, K. \& Taki, Y. Ontogenic development of the Weberian apparatus in the bitterling, Rhodeus ocellatus ocellatus. Tokyo Univ. Fisheries, 79:196200, 1992.

Gayet, M. Contribuition à l'etude anatomique et systématique de l'ichthyofaune Cénomanien du Portugal, deuxième partie: les ostariophysaires. Comun. Serv. Geol. Portugal, 67:173-90, 1981.

Gayet, M. Contribuition à l'etude anatomique et systématique de l'ichthyofaune Cénomanien du Portugal, troisième partie: complè ment à l'ètude des ostariophysaires. Comun. Serv. Geol. Portugal, 71:91-118, 1985.

Gayet, M. About ostariophysan fishes: a reply to S. V. Fink, P. H. Greenwood and W. L. Fink's criticisms. Bull. Mus. Natl. Hist. Sec. C, 8:393-409, 1986a.

Gayet, M. Ramallichthys Gayet du Cénomanien inférieur marin de Ramallah (Judée), une introduction aux relations phylogénétiques des Ostariophysi. Mém. Mus. Natl. Hist. Nat. Sér. C., 51:1-81, $1986 \mathrm{~b}$.

Gayet, M. \& Chardon, M. Possible otophysic connections in some fossil and living ostariophysan fishes. Proc. Vth Congr. Eur. Ichthyol. Stockholm, 31-42, 1987.

Gibbs, S.; Collard, M. \& Wood, B. A. Soft-tissue characters in higher primate phylogenetics. Proc Natl Acad Sci US, 97:11130-2, 2000.

Gibbs, S., Collard, M. \& Wood, B. A. Soft-tissue anatomy of the extant hominoids: a review and phylogenetic analysis. $J$. Anat., 200:3-49, 2002.

Gould, S. J. The structure of evolutionary theory. Harvard, Belknap, 2002.

Graham, A. Vertebrate evolution: turning heads. Current Biol., 15:764-6, 2005

Grande, L. Recent and fossil clupeomorph fishes with materials for revision of the subgroups of clupeoids. Bull. Amer. Mus.
Nat. Hist., 181:231-372, 1985.

Grande, T. \& Poyato-Ariza, F. J. Phylogenetic relationships of fossil and recent gonorynchiform fishes (Teleostei: Ostariophysi). Zool. J. Linn. Soc., 125:197-238, 1999.

Grande, T. \& Braun, C. Evolution of the Weberian apparatus. Bioacoustics, 12:120-2, 2002.

Grande. T. \& Shardo, J. D. Morphology and development of the postcranial skeleton in the channel catfish Ictalurus punctatus (Ostariophysi: Siluriformes). Fieldiana, 1518:1-30, 2002.

Grande, T. \& De Pinna, M. C. C. The evolution of the Weberian apparatus: a phylogenetic perspective. In Arratia, G. \& Tintori, A. eds. Mesozoic fishes 3 - Systematic, Paleoenvironments and Biodiversity. München, Verlag Dr. F. Pfeil, 2004. pp. 429448.

Grande, T. \& Young, B. The ontogeny and homology of the Weberian apparatus in the zebrafish Danio rerio (Ostariophysi: Cypriniformes). Zool. J. Linn. Soc., 140:241-54, 2004.

Greenwood, P. H. \& Rosen, D. E. Notes on the structure and relationships of the alepocephaloid fishes. Amer. Mus. Novit., 2473:1-41, 1971.

Heyd, A. \& Pfeiffer, W. Über die Lauterzeitung der Welse (Siluroidei, Ostariophysi, Teleostei) und ihren Zusammenhang mit der Phylogenie und der Schreckreaktion. Rev. Suisse Zool., 107:165-211, 2000.

Hoedemann, J. Studies on callichthyid fishes. 3. Notes on the development of Callichthys. (1) (Pisces Siluriformes). Bull. Aquatic Biol., 19:53-72, 1960a.

Hoedemann, J. Studies on callichthyid fishes. 5. Development of the skull of Callichhtys and Hoplosternum (2). (Pisces Siluriformes). Bull. Aquat Biol., 2:21-36, $1960 \mathrm{~b}$.

Ichiyanagi, T.; Kohno, H. \& Fujita, K. Ontogenetic development of the Weberian apparatus in the silurid catfish, Silurus asotus. J. Tokyo Univ. Fisheries, 80:205-11, 1993.

Ichiyanagi, T.; Kohno, H. \& Fujita, K. Ontogenetic development of the Weberian ossicles in the bagrid catfish, Pseudobagrus ichikawai. J. Tokyo Univ. Fisheries, 84:93-7, 1997.

Ichiyanagi, T., Kohno, H., Fujita, K. \& Taki, Y. Ontogenetic development of the Weberian ossicles in two cyprinids, Triblodon hakonensis and Zacco platypus. J. Tokyo Univ. Fisheries, 82:119-24, 1996.

Kulshrestha, S. K. Development of the Weberian apparatus in the major carp Labeo rohita (Ham.). Anat. Anz., 141:433-44, 1977. 
Kleerekoper, H. \& Roggenkamp, P. An experimental study of the effect of the swim bladder on hearing sensitivity in Ameiurus nebulosus nebulosus (Lesieur). Can. J. Zool., $37: 1-8,1959$.

Köntges, G. \& Lumsden, A. Rhombencephalic neural crest segmentation is preserved throughout craniofacial ontogeny. Development, 122:3229-42, 1996.

Mabee, P. M. An empirical rejection of the ontogenetic polarity criterion. Cladistics, 5:409-16, 1989a.

Mabee, P. M. Assumptions underying the use of ontogenetic sequences for determining character state order. Trans. Am. Fish Soc., 118:151-8, 1989b.

Mabee, P. M. Phylogenetic interpretation of ontogenic change: sorting out the actual and artefactual in an empirical case study of centrarchid fishes. Zool. J. Linn. Soc., 107:175291, 1993.

Patterson, C. Chanoides, a marine eocene otophysan fish (Teleostei: Ostariophysi). J. Vert. Paleont., 4(3):430-56, 1984.

Patterson, C. \& Johnson, G. D. The intermuscular bones and ligaments of teleostean fishes. Smithson. Contrib. Zool., 599:1-83, 1995.

Poggendorf, D. Die absoluten Hörschwellen des Zwergwelses (Amiurus nebulosus) und Beiträge zur Physik des Weberschen Apparates der Ostariophysen. Z. vergl. Physiol., 34:222-57, 1952.

Popper, A. N. The Morphology of the Weberian Ossicles of Two Species of the Genus Astyanax (Ostariophysi : Characidae). J. Morphol., 133:179-88, 1971.

Radermaker, F.; Surlemont, C.; Sanna, P.; Chardon, M. \& Vandewalle, P. Ontogeny of the Weberian apparatus of Clarias gariepinus (Pisces Siluriformes). Can. J. Zool., 67:2090-7, 1989.

Rosen, D. E. \& Greenwood, P. H. Origin of the Weberian apparatus and the relationships of the ostariophysan and gonorynchiform fishes. Am. Mus. Novit., 2428:1-25, 1970.

Sagemehl, M. Beiträge zur vergleichenden Anatomie der Fische. III. Das Cranium der Characiniden nebst allgemeinen Bemerkungen über die mit einem Weber'schen Apparate versehenen Physostomen Familien. Morph. Jb., 10:1-11, 1885 .

Schreiber, B. La funzione dell'apparato de Weber. Ricerche sperimentali sui Cyprinidi. Arch. Zool. Torino, 21:1-10, 1935.
Shoshani, J., Groves, C. P., Simons, E. L. \& Gunnell, G. F. Primate phylogeny: morphological vs. molecular results. Mol. Phylogenet. Evol., 5:101-53, 1996.

Taverne, L. Description de l'appareil de Weber du téléosteen crétacé marin Clupavus maroccanus et ses implications phylogénétiques. Belg. J. Zool., 125(2):267-82, 1995.

Taverne, L. Les poissons cretacés de Nardò, $8^{\circ}$ - Sorbininardus apuliensis, gen. nov., sp. Nov. (Teleostei, Ostariophysi, Anatophysi, Sorbininardiformes, nov. ord.). Studi $e$ Richerche sui giacimenti terziari di Bolca VIII, Spec Vol L Sorbiri, Mus. Civ. St. Nat. Verona, 23:77-103, 1999.

Taverne, L. Les poissons cretaces de Nardò, $20^{\circ}$ - Chanoides chardoni sp. nov. (Teleostei, Ostariophysi, Otophysi). Boll. Mus. Civ. St. Nat. Verona, 29:39-54, 2005.

Vandewalle, P. Contribution à l'étude anatomique et fonctionnelle de la région céphalique de Gobio gobio (L.) (Pisces, Cyprinidae), 3, les os, les muscles et les ligaments. Forma et Functio, 8:331-60, 1975.

Vandewalle, P.; Victor, D.; Sanna, P. \& Surlemont, C. The Weberian apparatus of a $18.5 \mathrm{~mm}$ fry of Barbus barbus. In H. Splechtna, G. Hilgers, eds. Trends in Vertebrate Morphology. Stuttgard, Fischer Verlag, 1989.V. 35.pp 3636.

Vandewalle, P.; Radermaker, F.; Surlemont, C. \& Chardon, M. Apparition of the Weberian characters in Barbus barbus (Pisces Cyprinidae). Z. Anz., 225:262-376, 1990.

Watson, J. M. The development of the Weberian ossicles and anterior vertebrae in the goldfish. Proc. Roy. Soc. Lond. B., 127:452-72, 1939.

Weber, E. H. De Aure et Auditu Hominis et Animalium: Pars I - De Aure Animalium aquatilium. Leipzig, Gehard Fleischer, 1820 .

Weiss, B.; Strother, W. \& Hartig, G. Auditory sensitivity in the Bullhead Catfish (Ictalurus nebulosus). Proc. Nat. Acad. Sci., 64:552-6, 1969.

\section{Correspondence to: \\ Dr. Rui Diogo \\ Department of Anthropology, \\ The George Washington University, \\ 2110 G St. NW, Washington, DC 20052, USA}

Email: Rui_Diogo@hotmail.com

Received: 07-07-2008

Accepted: 12-02-2009 